\title{
Comparing the impact of three different experiential approaches to entrepreneurship in education
}

\author{
Martin Lackéus \\ Department of Technology Management and Economics, \\ Chalmers University of Technology, Gothenburg, Sweden
}

\begin{abstract}
Purpose - Three different pedagogical approaches grounded in three different definitional foundations of entrepreneurship have been compared in relation to their effects on students. They are: (1) "Idea and ArtefactCreation Pedagogy" (IACP), grounded in opportunity identification and creation, (2) "Value-Creation Pedagogy" (VaCP), grounded in value creation and (3) "Venture-Creation Pedagogy" (VeCP), grounded in organisation creation. Design/methodology/approach - Data were collected at 35 different sites where education was deemed to be entrepreneurial and experiential. A quantitative, smartphone app-based data collection method was used alongside a qualitative interview approach. 10,953 short-survey responses were received from 1,048 participants. Responses were used to inform respondent selection and discussion topics, in 291 student and teacher interviews. Comparative analysis was then conducted.

Findings - The three approaches resulted in very different outcomes, both in magnitude and in kind. VaCP had strong effects on entrepreneurial competencies, on student motivation and on knowledge and skills acquisition. VeCP had weaker effects on knowledge and skills acquisition. IACP had weak effects on all outcomes probed for. Differences were attributed to variation in prevalence of certain emotional learning events and to variation in purpose as perceived by students.

Research limitations/implications - VaCP could serve as an escape from the potential dilemma faced by many teachers in entrepreneurial education, of being caught between two limiting courses of action; a marginal VeCP approach and a fuzzy IACP one. This could prompt policymakers to reconsider established policies. However, further research in other contexts is needed, to corroborate the extent of differences between these three approaches.

Originality/value - Most impact studies in experiential entrepreneurial education focus only on organisationcreation-based education. This study contributes by investigating entrepreneurial education that is also grounded in two other definitional foundations. Allowance has been made for novel comparative conclusions.
\end{abstract}

Keywords Enterprise education, Entrepreneurship education, Entrepreneurial education

Paper type Research paper

\section{Introduction}

Educational impact assessment is about searching for causal relationships between educational causes and their effects on students (Cook, 2002). A trend towards accountability in society makes it increasingly important for policymakers, teachers and other stakeholders in society to go beyond opinions and fashions and move towards robust evidence around the effects of different pedagogical [1] approaches on students (Ball, 2013; Slavin, 2002). Teachers need input on how to produce effects of interest, and education policymakers need to know which education "works". But education is an ontologically

(C) Martin Lackéus. Published by Emerald Publishing Limited. This article is published under the Creative Commons Attribution (CC BY 4.0) licence. Anyone may reproduce, distribute, translate and create derivative works of this article (for both commercial and non-commercial purposes), subject to full attribution to the original publication and authors. The full terms of this licence may be seen at http:// creativecommons.org/licences/by/4.0/legalcode.

This paper forms part of a special section Filling in the Blanks: 'Black Boxes' in Enterprise/ Entrepreneurship Education guest edited by Helle Neergaard, William B. Gartner, Ulla Hytti, Diamanto Politis and David Rae.
Entrepreneurship in education

Received 23 April 2018 Revised 7 February 2019 20 June 2019 
IJEBR

26,5

938 challenging phenomenon. Causes and effects are often internally related (Biesta, 2009). Causal regularities are also weak in education, since the main object of study is meaning-making humans, with a will of their own, acting in an open-ended system (Sayer, 2010).

In terms of entrepreneurial causes, there are many different pedagogical approaches to entrepreneurship in education. Students can be asked to: (1) start a real-life business venture (Ollila and Williams-Middleton, 2011); (2) start a simulated mini-company (Dwerryhouse, 2001; European Commission, 2005); (3) start a social venture (Rae, 2010; Young, 2014); (4) write a business plan (Honig, 2004; Neck et al., 2014); (5) sit around a table and brainstorm ideas (Gibb, 2008); (6) listen to a successful entrepreneur telling war stories from the entrepreneurship trenches (Katz, 2008); or (7) spend time working for an entrepreneur (Kubberød and Pettersen, 2017). There are also many different entrepreneurial effects. In addition to increased knowledge about entrepreneurship, students can also develop a broad variety of skills and attitudes, such as leadership, creativity, self-insight, self-efficacy, school engagement, learning orientation, proactiveness, perseverance, uncertainty tolerance and increased intention to start a venture (Bacigalupo et al., 2016; Fisher et al, 2008; Moberg, 2014a).

While causes and effects are numerous and contextual in entrepreneurial education, impact assessment is more simplistic and macro-level-focused (Brentnall et al., 2018). In terms of causes, most assessment studies have adopted a narrow, business-orientated view of entrepreneurship as "starting new organisations" (Pepin and St-Jean, 2018). There is also widespread confusion around different, largely incommensurable pedagogical approaches being compared alongside each other (Fayolle, 2013). Traditional lecturing about entrepreneurship is often compared to highly experiential learning-by-doing approaches, without explicitly acknowledging the fundamental pedagogical differences (Kozlinska, 2016). This has led to contradictory and inconclusive findings (Nabi et al., 2017). In terms of effects, most assessment studies rely on a narrow view of entrepreneurship, assessing the resulting intention and perceived ability among students to start a new organisation (Kozlinska, 2016). The strongest effects are believed to emanate from experiential hands-on and learning-bydoing-orientated approaches (Barr et al, 2009; Gielnik et al., 2015; Günzel-Jensen et al., 2017; Nabi et al.,2017). But what "works" is still an unresolved debate (Hägg and Gabrielsson, 2019).

Therefore, recent calls have emerged for assessment studies that pay more heed to different pedagogical choices. Fayolle (2013, p. 696) calls for studies that "set out to compare the effectiveness and efficiency of different teaching methods". Kozlinska (2016, p. 38) states that there is a need for "explicit comparisons between different forms of interventions in entrepreneurship". Nabi et al. (2017, p. 292) call for assessment research that "rigorously isolates the impact of a pedagogical intervention", stating that it is "the only way for us to understand entrepreneurship education impact in an incremental and meaningful way." Moreover, it is important, in educational research, to value not only that which is easy to measure (in this case, entrepreneurial intentions and self-efficacy) but to also engage in more challenging attempts to measure that which we value; including, more broadly, students' development of entrepreneurial competencies and the underlying causal learning mechanisms which produce these broad effects (cf. Biesta, 2009; Ylikoski, 2019).

As a response to these calls, the purpose of this study has been to investigate what difference it makes for students when teachers apply one of three different, experiential, pedagogical approaches, grounded in three different definitions of entrepreneurship. These three different approaches have been compared empirically: (1) idea and artefact-creation pedagogy (IACP) grounded in an opportunity-based definition of entrepreneurship (Shane, 2003), (2) value-creation pedagogy (VaCP), grounded in a new value-creation-based definition of entrepreneurship (Bruyat and Julien, 2001), and (3) venture creation pedagogy (VeCP) grounded in an organisation-creation-based definition of entrepreneurship (Gartner, 1989). All three approaches are examples of experiential entrepreneurial education, that is, when teachers apply action-based pedagogy that is deemed to be "entrepreneurial" as a formal part 
of education. What is deemed "entrepreneurial" depends upon which definitional stance teachers have taken on entrepreneurship, implicitly or explicitly. To investigate the effects on students, the three approaches have been compared in regard to: (1) developed entrepreneurial competencies, (2) learning of subject matter knowledge and skills and (3) engagement and motivation. The study thus explores the following key question: how do IACP, VaCP and VeCP compare, in terms of their effects on students? The objective is to produce better guidance for teachers considering which pedagogical approach to opt for, given their context and the effects they want to achieve.

In an attempt to overcome the incommensurability challenge when comparing vastly different pedagogical approaches, an emotion-centric and longitudinal mixed-methods research design was applied. Anchoring the comparison in emotionality made a cross-case analysis possible, despite significant pedagogical variation. Six data collection and analysis waves were conducted, from 2012 to 2016 , by the same team of researchers and with the same methodology. In a quantitative and longitudinal phase, 10,953 emotional learning events were collected through a digital app from 1,048 students, in 35 different settings, across three countries and from all levels of education. In a subsequent qualitative phase, 291 interviews were conducted, transcribed and analysed.

The article is structured as follows. Firstly, the three experiential pedagogical approaches are presented and related to entrepreneurship theory and learning theory. This is followed by a review of previous work on assessment in entrepreneurial education. The data collection and analysis methods applied in the six waves are then described. Next, the findings are presented, both in terms of what happened at the 35 sites studied and what effects on students could be observed. Finally, the discussion elaborates on the patterns and addresses possible explanations and implications, based on the findings.

\section{Three pedagogical approaches to entrepreneurship in education}

To assess the effects of an education intervention, it is important, first of all, to be able to classify and define it (Pring, 2010). Many attempts to classify and define entrepreneurial education are grounded in pedagogy. One of the most-used classifications in the field, teaching "about", "for" or "through" entrepreneurship, is based on pedagogical differences (Aadland and Aaboen, 2018). The "about" approach is primarily connected to traditional passive teaching, through lectures, case studies and group discussions. The "for" and "through" approaches are connected to various active and self-directed learning modes (Hannon, 2005; Pittaway and Cope, 2007). Another widespread pedagogy-based classification specifies five aspects of entrepreneurial education that contribute to differentiation: objectives, target audiences, contents, pedagogical methods and intended outcomes (Fayolle and Gailly, 2008).

However, pedagogy-based classifications might risk diluting entrepreneurial education into yet another synonym describing variation already covered by other terms from educational researchers (Hägg, 2016; Leffler, 2009; Neck and Corbett, 2018). Therefore, rather than relying on pedagogy-based classifications, this article will use the multi-faceted definitional core of entrepreneurship to bring theoretical rigour to the comparison. Three different pedagogical approaches have been selected for inclusion, based on whether they are dominant or promising.

A dominant classification of entrepreneurial education is a British dichotomy, dividing the field into a narrow approach, termed "entrepreneurship education" and a broad approach, termed "enterprise education" (Gibb, 2002; Hannon, 2018). The former is defined as learning about and through business start-up, the latter as education aiming at developing the competencies necessary to generate and realise ideas (Hannon, 2018; Jones and Iredale, 2010; QAA, 2012, 2018). According to Dal et al. (2016), the dichotomy has siblings in many other European countries. The catch-all term "entrepreneurial education" is sometimes used of both approaches (QAA, 2018). 
IJEBR

26,5

940

\subsection{The organisation-creation approach: entrepreneurship education}

As entrepreneurship education relies on a business start-up logic, its definition is grounded primarily in an organisation-creation view of entrepreneurship (Neck and Corbett, 2018). This leans on Gartner's (1989, p. 62) classical definitional assertion that "Entrepreneurship is the creation of new organisations". One approach to organisation creation in education is minicompany programmes, provided worldwide by Young Enterprise and others. Students run a business for one or two semesters, then liquidate it (Dwerryhouse, 2001; European Commission, 2005). Another approach is the full-venture-creation approach provided by some universities. Students learn by creating a real-life venture, with the intention of incorporating it after graduation if it succeeds in its market (Ollila and Williams-Middleton, 2011).

\subsection{The opportunity-creation approach: enterprise education}

The definitional foundations of enterprise education are more contested (Draycott and Rae, 2011; Jones and Iredale, 2010). Enterprise education might even be viewed as relying on an inverted definitional foundation, concerning all the remaining pedagogies deemed "entrepreneurial" once organisation creation has been ruled out (Hägg, 2016). Still, if there is one definitional perspective which dominates pedagogical discussions around enterprise education more than others, it would be opportunity identification and creation. Gibb (2008, p. 105) states that an enterprising person is "seeking and exploiting opportunities". Jones and Iredale (2010, p. 13) state that "the emphasis of enterprise education pedagogy is on the freedom of the individual to change, grow, develop, act on and adapt to opportunities". Draycott and Rae (2011, p. 138) have stated that enterprise education is about "the development of self-knowledge and self-efficacy to be able to investigate, develop and act on ideas and opportunities". In line with these statements, the Quality Assurance Agency for Higher Education in the UK has defined enterprise education as teaching that is "enabling students to be more opportunityfocused” (QAA, 2012, p. 8-9). This definition was later refined into enterprise education being about "the generation and application of ideas" (QAA, 2018, p. 7). Enterprise education is thus definitionally well-aligned with Shane and Venkataraman's (2000, p. 218) well-known claim that entrepreneurship can be defined as "the nexus of two phenomena: the presence of lucrative opportunities and the presence of enterprising individuals".

\subsection{The value-creation approach: entrepreneurship viewed as new value creation}

An emerging and promising definitional perspective, increasingly being discussed in entrepreneurial education, is that of viewing entrepreneurship as new value creation (Blenker et al., 2011; Fayolle, 2007; Jones, 2011; Vestergaard et al., 2012). This leans definitionally on work by Bruyat (1993, p. 63) and Bruyat and Julien (2001, p. 174), who proposed that: (1) when someone creates something that is both novel and valuable for others and (2) when that person also learns and develops profoundly from the undertaking, people tend to label it as entrepreneurship. Creating new kinds of value is a much broader activity type than creating a new organisation or a new business opportunity and can be seen in many people's "everyday practice" in all societal sectors (Blenker et al., 2011). Viewing entrepreneurship as new value creation is thus both a broader and more learning-orientated definition of entrepreneurship than the more established organisation-creation or opportunity-creation definitions. Such a view, therefore, comes with important educational implications; for example, a need to involve all students in entrepreneurial education (Blenker et al., 2011). Value-creation methods may even need to become "an essential part of basic education" so that all students are taught entrepreneurial methods that can unleash the value-creating "potential of human nature"; just as scientific methods are taught to all students (Sarasvathy and Venkataraman, 2011, p. 120 and p. 129).

Applied to teaching, an experiential, value-creation approach can be about "letting students learn by applying their existing and future competencies to create something 
preferably novel of value to at least one external stakeholder outside their group, class or school" (Lackéus et al., 2016, p. 790). Students can be given an opportunity "to conceive value, to attempt to create value, to attempt to capture any such value, and finally, to critique their efforts to do so" (Breslin and Jones, 2014, p. 438). The value that students create for others may be economic, social, ecological, mental, physical, etc. (cf. Hindle, 2010; Korsgaard and Anderson, 2011). Even if the main purpose of education is not letting students create value for others, it can still constitute a useful means of fostering deeper student learning and engagement (Sagar, 2015). The value-creation approach represents an altruistic and relational turn in entrepreneurial education, in which adopting a "students-as-givers" perspective can help mitigate problematic neoliberal [2] tendencies in entrepreneurial education (Berglund, 2013; Komulainen et al., 2011; Lackéus, 2017).

\subsection{A typology of experiential entrepreneurial education}

The emerging new value-creation approach to entrepreneurship in contemporary entrepreneurial education illustrates a potential problem. Has the implicit definitional assumption of enterprise and entrepreneurship education (interpreted primarily as opportunity identification and organisation creation respectively) become problematic? Has its emphasis on two main definitional perspectives led to a silent narrowing of people's minds, leaving other definitional perspectives curtailed? An illustration of this potential problem is the recent and somewhat dichotomised discourse around an "overly broad" and dangerously diluted enterprise education approach versus an "overly narrow" and exclusionary, businessorientated entrepreneurship education approach (cf. Draycott and Rae, 2011; Jones and Iredale, 2010; Jones et al., 2019, p. 1174; Neck and Corbett, 2018, pp. 29-30). While dualistic frameworks offer compelling simplicity, they can also trigger impoverished and shallow thinking (Barrett, 1979; Damasio, 1994; Tobias and Duffy, 2009).

Therefore, this study uses a more fine-grained and four-pronged typology of experiential entrepreneurial education, recently proposed by Lackéus and Sävetun (2019). In this typology [3], enterprise and entrepreneurship education are each split into two sub-categories, as illustrated in Figure 1. The four approaches shown form a four-step progression model, illustrating the importance of teachers adjusting their pedagogical approach as students progress through the entire education system (Blenker et al., 2011; Gibb, 2008; Rasmussen and Nybye, 2013). Figure 1 represents an ideal situation, in which students get to experience the full progression in convenient succession. In reality, most students only get to experience a single, isolated pedagogical approach (Pepin and St-Jean, 2018).

The first step in Figure 1 involves an opportunity identification or creation process, in which students come up with ideas and create artefacts in the classroom, such as plans, reports, concepts, artwork, presentational materials or prototypes. This step is therefore termed "idea and artefact creation pedagogy" (IACP). In the second step, students apply their ideas and

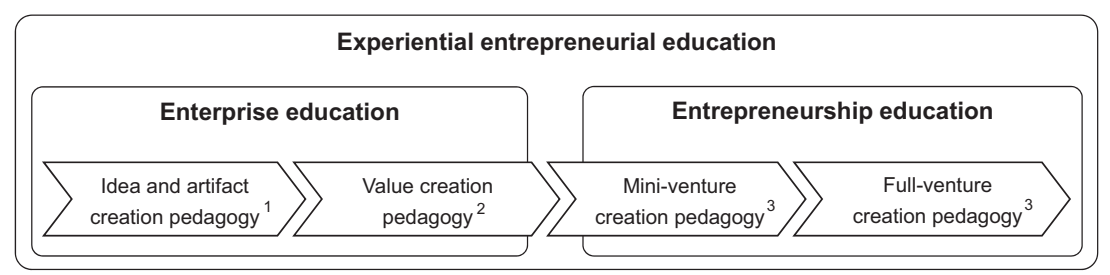

Note(s): 1: Definitional basis in opportunity identification/creation, as defined by Shane

2: Definitional basis in new value creation, as described by Bruyat

3: Definitional basis in organisational emergence, as defined by Gartner
Entrepreneurship in education

\section{1}

Figure 1.

A pedagogical progression model for experiential entrepreneurial education, based on definitional

foundations of entrepreneurship. 
IJEBR

26,5

942

artefacts as they attempt to create different types of tangible, real-world value for potential stakeholders outside their group, classroom or school; termed "value-creation pedagogy" (VaCP). The third step focuses on establishing a new organisation around the value-creating endeavour. Since a dominant approach is mini-company programmes (Dwerryhouse, 2001; European Commission, 2005), this step is termed "mini-venture creation pedagogy" (mini-VeCP). The fourth step represents a more full-fledged, and often innovation-based, venture-creation approach, in which students incorporate their venture, if it proves successful (Ollila and Williams-Middleton, 2011) and termed "full-venture creation pedagogy" (full-VeCP). In this article, mini-VeCP and full-VeCP are discussed collectively as "VeCP" [4], since they are both grounded in an organisation-creation-based definition of entrepreneurship.

\subsection{Relating the three pedagogical approaches to learning theory}

To form a foundation for subsequent analysis of findings, the typology in Figure 1 will now be used to relate the three pedagogical approaches (IACP, VaCP and VeCP) to extant learning theory. It is often recommended that entrepreneurial education should include learning-bydoing or experiential learning (Pepin, 2012; Ramsgaard, 2018). While there is little consensus around exactly what experiential learning is (Roberts, 2012), many associate it with active, hands-on, learning-by-doing, in the classroom or outside of it (Fayolle, 2013; Hägg and Kurczewska, 2016). Thus, an examination of what students should do, more specifically, allows for different entrepreneurial education approaches to be linked to different experiential traditions in learning theory (cf. Biggs and Tang, 2011).

In IACP, students frequently learn from a self-directed, team-based creative process, in which they analyse problems and then design some kind of artefact that may or may not solve a problem. This links IACP to problem-based learning (Savery and Duffy, 1995; Tan and Ng, 2006), project-based learning (Blumenfeld et al., 1991; Gibb, 2002), cooperative learning (Hytti et al., 2010; Johnson et al., 2000), constructivist learning (Löbler, 2006; Tobias and Duffy, 2009) and design-based learning (Neck and Greene, 2011; Puente et al., 2013). It also links IACP more generally to progressive education (Erkkilä, 2000; Leffler, 2009), a centuriesold tradition that emphasises student-centric pedagogy (see further Egan, 2002; Labaree, 2005) and with roots in the work of Rousseau (1762), Montessori (1912) and Dewey (1938).

In $\mathrm{VaCP}$, students direct their activities outward, as they attempt to create tangible value for external stakeholders, preferably in the surrounding community. In addition to the previously mentioned learning theories, this also links VaCP to: service-learning (Furco, 1996; McCrea, 2009), socially situated learning (Kubberød and Pettersen, 2017; Lave and Wenger, 1991), pedagogy of work (Carlin and Clendenin, 2019; Freinet, 1993) and work-integrated learning (Dhliwayo, 2008; Kaider et al., 2017). VaCP also has centuries-old roots, as illustrated by the apprenticeship model which emerged in the Middle Ages, when guilds of artisans and merchants started to organise work-integrated learning (Harris and Deißinger, 2003; Richard, 2012).

In $\mathrm{VeCP}$, students organise their creative and value-creating activities into a legal entity. While this also triggers many of the activities associated with IACP and VaCP (and thus relates to most or all of the above-mentioned learning theories), it is arguably more difficult to anchor the creation of a legal entity in a particular tradition of learning theory.

\section{Previous work on assessing the effects of IACP, VaCP and VeCP}

In assessing entrepreneurial education, it is not uncommon to see IACP being assessed alongside $\mathrm{VeCP}$, without acknowledging the substantial pedagogical and entrepreneurshipgrounded definitional differences (for a recent example, see Chatzichristou et al., 2015). Such compounding is challenging, since listening passively to a teacher will not produce the same 
effects on students as engaging them in generating business ideas and writing business plans (IACP), or letting them start a more-or-less real venture (VeCP) (Aadland and Aaboen, 2018; Nabi et al., 2017). This incommensurability between different pedagogical approaches could be one reason why meta-studies on the effects of entrepreneurial education have so far turned out to be largely inconclusive (Bae et al., 2014; Martin et al., 2013). Conducting comparative or meta-studies on the effects of different pedagogical approaches can be a futile endeavour, without a fine-grained definitional or pedagogical framework to guide the work (Nabi et al., 2017).

At the level below meta-studies, many individual studies have shown strong positive effects of VeCP on students' entrepreneurial knowledge, skills and attitudes (for example, Barr et al., 2009; Elert et al., 2014; Johansen and Clausen, 2011; Peterman and Kennedy, 2003; Rasmussen and Sørheim, 2006). Mini-VeCP is the most-assessed type, especially the minicompany programme provided by Young Enterprise. A consensus is emerging among scholars that action-based approaches produce the strongest effects, since authentic and reallife mastery experiences build higher-level behavioural competencies (Barr et al., 2009; Gielnik et al., 2015; Günzel-Jensen et al., 2017; Nabi et al., 2017). When students get to create real-life value for external stakeholders, in a full-fledged business startup process embedded in a supportive and sharing environment, it triggers a powerful, emotional roller-coaster that develops entrepreneurial self-efficacy, passion, identity and a personal career vision (Haneberg and Aadland, 2019; Lackéus, 2014). Alongside individual studies showing that some VeCP programmes do seem to produce strong effects on students, there is an ongoing discussion (mainly among quantitative research methodology scholars) around whether or not entrepreneurship education "works" (Kozlinska, 2016; Longva and Foss, 2018; Martin et al., 2013). To summarise the assessment situation for VeCP, there is an abundance of qualitative accounts of strong effects on students in selected programmes, but a paucity of rigorous quantitative and longitudinal impact studies based on randomisation and control groups (an exception is Gielnik et al., 2015).

Impact assessment of IACP is rare. Jones and Iredale (2010) have even claimed that, due to definitional ambiguity, there is no robust way to assess enterprise education. The few attempts made have been both difficult and disappointing (Pepin and St-Jean, 2018). Moberg (2014b) used a pedagogical definition base to circumvent the definitional challenge and then found that entrepreneurial intentions were reduced by IACP. Another attempt to assess IACP, with a definitional base grounded in entrepreneurship, found the effects to be disappointing (Lackéus and Sävetun, 2019). The scarcity of evidence does not, therefore, support the idea of IACP having strong effects on students. When it comes to VaCP, there seems to be no record of studies establishing its impact.

Assessing entrepreneurial education has thus remained a scattered and challenging endeavour, both within and between different types of entrepreneurial education. To date, none of the four pedagogical approaches to entrepreneurial education in Figure 1 seem to have been adequately assessed, and a rigorous and definitionally fine-grained comparison between them is lacking.

\section{Methodology}

According to a centuries-old classification, the human mind may be divided into three different parts: thoughts, actions and emotions (Hilgard, 1980). This became the unusual starting point of an innovative approach to comparative impact assessment of experiential entrepreneurial education. Many existing assessment approaches involve surveys probing for people's thoughts or actions before, during or after an intervention. To overcome the incommensurability challenge of assessing entrepreneurial education, an emotion-centric approach was opted for instead, since not only entrepreneurial learning (Cope, 2003; Gibb, 
IJEBR

26,5

944

2002; Kyrö, 2005; Pittaway and Cope, 2007; Souitaris et al., 2007) but also all learning contains, and thrives on, emotions (Boekaerts, 2010; Jarvis, 2006; Postle, 1993). Indeed, emotions help students learn cognitive material more effectively; so much so that the presence of emotionality may be viewed as an indicator of learning (Jones and Underwood, 2017). Further, since emotions are omnipresent in learning (Chabot and Chabot, 2004), an emotion-centric analytical lens could be a particularly powerful tool in a comparative study. Similarities and differences observed may be anchored in emotionality, thus allowing for robust cross-case comparisons, despite significant pedagogical variation.

All empirical data in this study were collected with this key methodological idea in mind, leaning on the concept of critical learning events (Cope, 2003; Cope and Watts, 2000; Flanagan, 1954; Rae, 2013; Snell, 1992). Such events are highly emotional and offer researchers a methodological "way in to studying entrepreneurial learning" (Cope and Watts, 2000, p. 108). Emotional learning events were therefore captured via both quantitative and qualitative research methods, to support the comparative analysis. Whenever an emotional learning event was captured empirically, it was posited as indicating that something significant and impactful was going on in the learning environment being studied and thus worthy of further comparative inquiry.

An emotion-based research approach allows for the establishment of a more fine-grained causal model than the common, idealised, two-component deductive-nomological model, in which the cause is (1) entrepreneurial education and the effect is (2) either the developed entrepreneurial competencies or other favoured effects, such as student motivation and deep learning (cf. Little, 1991, pp. 14-15). Rather, a three-component causal model is relied upon here. Links are identified and analysed among (1) different experiential pedagogical approaches, (2) triggered emotional learning events and (3) the resulting outcomes in terms of developed entrepreneurial competencies, deeper student learning and increased student motivation (see Figure 2). This allows for a detailed analysis of those causal mechanisms that mediate between cause and effect and potentially opens up the black box of how, when and why any desired effects are produced through experiential entrepreneurial education (Hedström and Ylikoski, 2010). Competencies that are deemed entrepreneurial include: knowledge of how entrepreneurs create value; skills in marketing, resource acquisition and opportunity identification; and attitudes such as entrepreneurial passion, self-efficacy, proactiveness and tenacity (Bacigalupo et al., 2016; Fisher et al., 2008).

Figure 2.

Three-component causal model (adapted and developed from Lackéus and Sävetun, 2019)

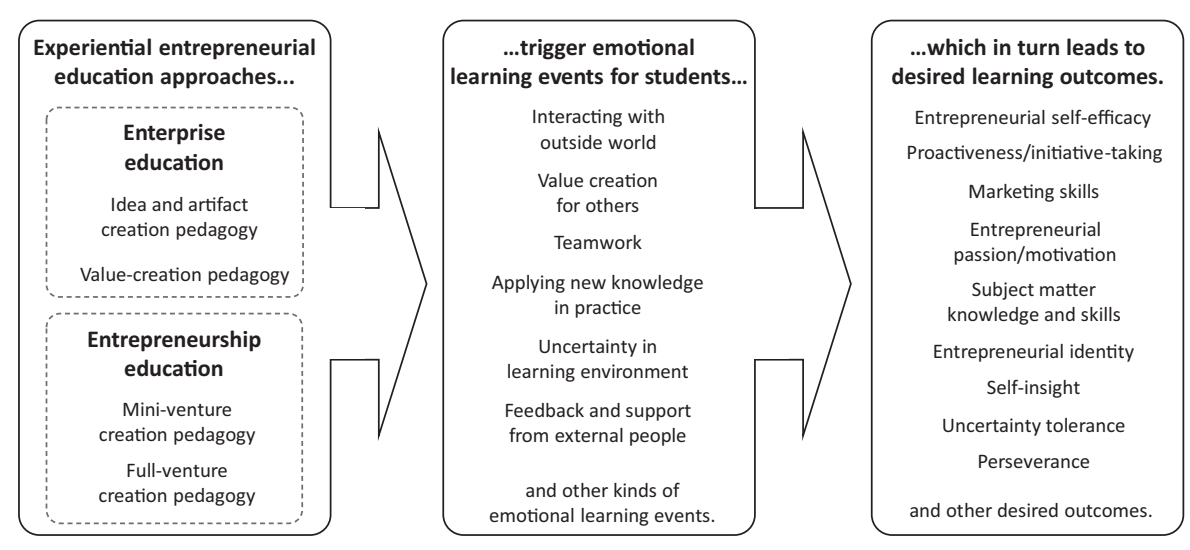

Source(s): adapted and developed from Lackéus and Sävetun, 2019 


\subsection{The 35 learning environments studied}

The data in this study were collected at 35 different sites in six waves [5], as summarised in Table 1. An internal report was written after each wave, allowing the research team to elucidate and summarise the findings thus far and to inform the sampling decisions and design of subsequent waves. The study design, research tool construction, data collection and analysis took seven years and involved a large number of people. To facilitate comparison, a balance was struck between different approaches to entrepreneurial education and different student ages (see Table 2). VaCP was the least-assessed pedagogical approach of the three investigated here. It was, therefore, more thoroughly investigated than IACP and VeCP, by including more VaCP sites and participants. Similarly, since compulsory [6] education was the least-studied age level in previous work, more focus was given to younger students than in previous research, by including more compulsory education sites and participants. Consequently, no data were collected on IACP in higher and adult education.

Learning environments [7] were included that applied one of the three studied approaches to experiential entrepreneurial education. Purposive and emergent reference-based sampling was the overall sampling strategy, but there were slight variations in sampling strategy both between and within waves. In wave 1 , site 1 was chosen, based on convenience sampling since the author is a teacher at a full-VeCP known for producing strong effects on students. In wave 2, sites were chosen which the author had come across through networking, as they were found to constitute rare and interesting examples of $\mathrm{VaCP}$ in compulsory education. The sampling strategy for wave 3 involved a collaboration with Swedish National Agency of Education and 30 contacted experts, who were asked to name particularly good examples of entrepreneurial education. In wave 4, sampling was based on discussions with Region Skåne, a major public funder for entrepreneurial education on all levels of education. It wanted to assess the impact of some of its most important funded initiatives. In wave 5, sampling was based on the preferred partners of Gothenburg Municipality; ones it trusted would perform well in an EU-funded project. In wave 6 , sampling was based on a call for $\mathrm{VaCP}$ participants through social media and through a national network based around entrepreneurial education. A short survey was conducted to ensure that each school worked with VaCP. Schools already known to use VaCP were encouraged to apply. All 35 learning environments chosen for inclusion were categorised according to a classification scheme shown in Figure 3.

\subsection{Data collection and analysis method}

The data collection and analysis method consisted of three different steps: (1) collecting emotional learning events from participants through a mobile app; (2) preparing, conducting and transcribing interviews with carefully selected students; and (3) analysing the generated app and interview data. These three steps are briefly explained below.

4.2.1 Step 1: deploy a mobile app that collects students' emotional learning events. Short surveys have been used since the 1970s to capture respondents' experiences directly in their natural environment (Hektner et al., 2007). This method is called the "experience sampling method" (ESM). Capturing subjective experiences with previously unattained precision allows a high level of validity to be obtained (Stone et al., 2003). A smartphone app [8] was developed so that ESM could be used for the empirical study described in this article. All participants in the 35 learning environments were instructed on how to use this app to submit emotional learning events experienced in their education. One "app report" was submitted for each emotional learning event.

Each app report started with a mandatory free-text reflection, describing the emotional event that had occurred. Then the participant categorised their emotions using a seven-step Likert scale from -3 to +3 , with -3 representing a very negative emotional event and +3 representing a very positive one. The participant also categorised the event by choosing one or several items from a set of predefined metadata tags, illustrating salient themes. Finally,

\section{Entrepreneurship} in education 
IJEBR

26,5

\section{6}

Table 1.

The 35 different learning environments studied

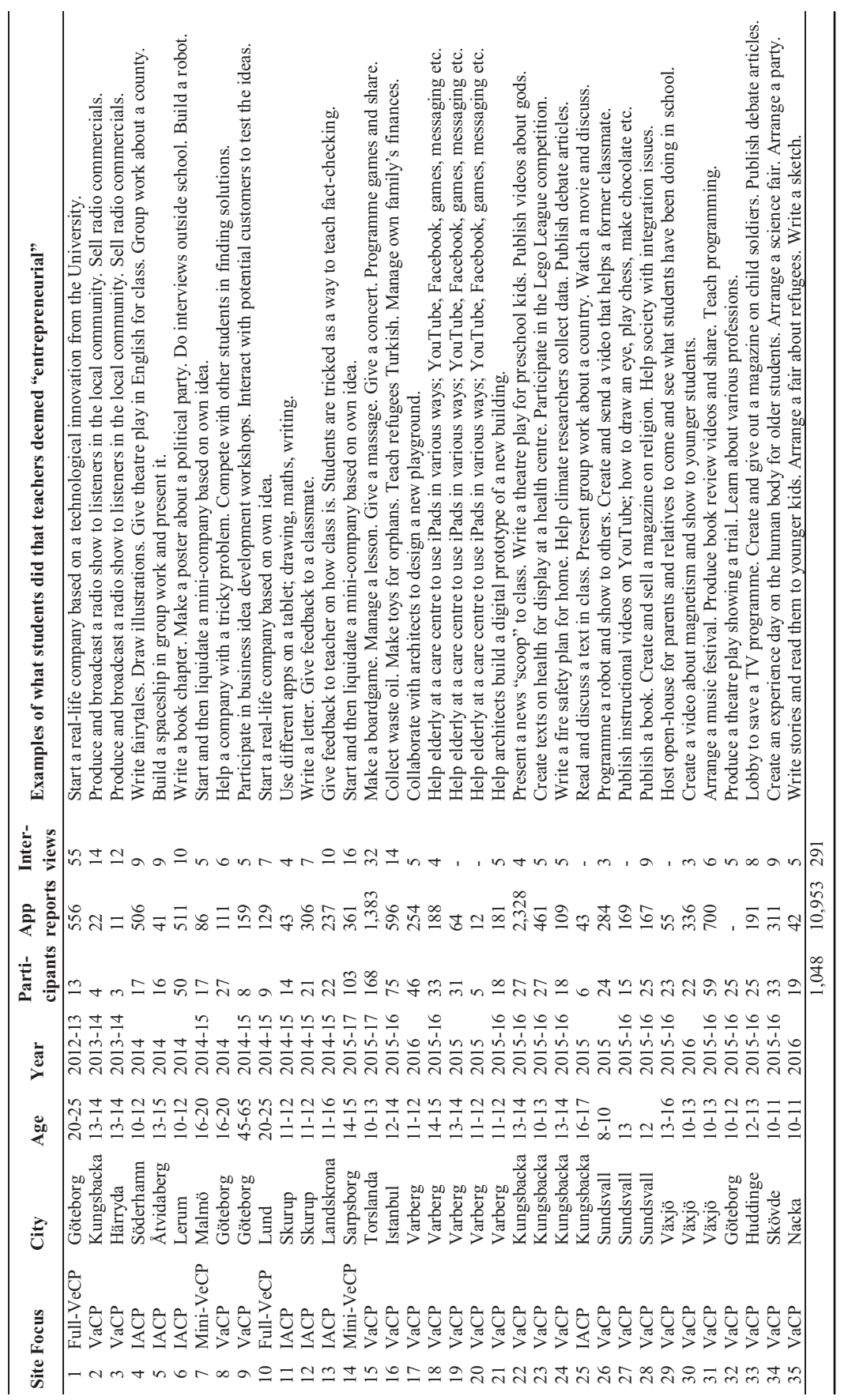




\begin{tabular}{|c|c|c|c|c|}
\hline & $\begin{array}{l}\text { Compulsory education } \\
\text { (9-15 years old) }\end{array}$ & $\begin{array}{l}\text { pper secondary education } \\
5-18 \text { years old) }\end{array}$ & $\begin{array}{l}\text { Higher and adult education } \\
\text { (18 years and older) }\end{array}$ & $\begin{array}{l}\text { Entrepreneurship } \\
\text { in education }\end{array}$ \\
\hline \multirow{2}{*}{$\begin{array}{l}\text { Idea and } \\
\text { artefact- } \\
\text { creation } \\
\text { pedagogy } \\
\text { (IACP) } \\
\text { Value-creation } \\
\text { pedagogy } \\
\text { (VaCP) }\end{array}$} & \multirow{2}{*}{$\begin{array}{l}190 \text { respondents from six } \\
\text { schools in Sweden, } \\
\text { submitting } 1910 \text { app } \\
\text { reports. } 49 \text { interviews } \\
\text { conducted and analysed } \\
725 \text { respondents from } 21 \\
\text { schools in Sweden and one } \\
\text { in Turkey, submitting } \\
7,907 \text { app reports. } 148 \\
\text { interviews conducted and } \\
\text { analysed }\end{array}$} & $\begin{array}{l}\text { x respondents from one } \\
\text { hool in Sweden, } \\
\text { bmitting } 43 \text { app reports. } \\
\text { o interviews conducted }\end{array}$ & (No data collected) & 947 \\
\hline & & $\begin{array}{l}27 \text { respondents from five } \\
\text { schools in Sweden, } \\
\text { submitting } 111 \text { app reports. } \\
\text { Six interviews conducted } \\
\text { and analysed }\end{array}$ & $\begin{array}{l}\text { Eight respondents from an } \\
\text { unemployment training } \\
\text { programme in Sweden, } \\
\text { submitting } 159 \text { app reports. } \\
\text { Five interviews conducted } \\
\text { and analysed }\end{array}$ & \\
\hline $\begin{array}{l}\text { Venture- } \\
\text { creation } \\
\text { pedagogy } \\
(\mathrm{VeCP})\end{array}$ & $\begin{array}{l}103 \text { respondents from a } \\
\text { school in Norway, } \\
\text { submitting } 361 \text { app reports. } \\
16 \text { interviews conducted } \\
\text { and analysed }\end{array}$ & $\begin{array}{l}17 \text { respondents from a } \\
\text { school in Sweden, } \\
\text { submitting } 86 \text { app reports. } \\
\text { Five interviews conducted } \\
\text { and analysed }\end{array}$ & $\begin{array}{l}22 \text { respondents from two } \\
\text { universities in Sweden, } \\
\text { submitting } 685 \text { app reports. } \\
62 \text { interviews conducted and } \\
\text { analysed }\end{array}$ & $\begin{array}{r}\text { respondents, app } \\
\text { reports and interviews } \\
\text { from each of the three } \\
\text { pedagogical } \\
\text { approaches }\end{array}$ \\
\hline
\end{tabular}

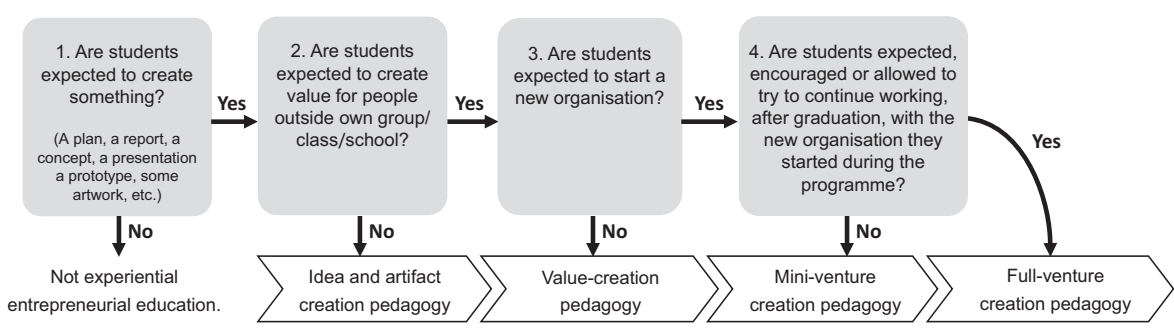

Figure 3.

A classification scheme used to categorise the main pedagogical approach of each studied learning environment

the app report was sent to their teacher and was visible to the teacher but not to other study participants. All app reports from all participants were also made available to the research team, in accordance with their written consent (or that of their parents, if the participant was younger than 15). When receiving a report, the teacher or coach could also interact in real-time with the participant through a chat function, producing additional empirical data.

4.2.2 Step 2: Prepare, conduct and transcribe interviews. The mainly quantitative data collected in step 1 using the ESM-based app report approach was fed into a more qualitative phase in step 2, with interview respondents as well as discussion topics largely chosen based on app reports. Thus, this was an app report-based sampling strategy as well as an app report-based interview template. These two steps acted as amplifiers, increasing the data quality of subsequent steps in the research process. The purpose of the interviews was to uncover links between the pedagogical approach, the triggered emotional learning events and the resulting effects on students. Each interview was prepared by compiling a summary of the most interesting and relevant app reports made by that participant. A semi-structured approach was used for the interviews: introduction, general lessons learned, app-induced questions around specific emotional learning events, other crucial emotional events in general, what had motivated the students, similarities and differences between this and other learning environments and recent important decisions made by the participant. Each time an emotional learning event was discussed, the participant was immediately and repeatedly asked to link that event to any learning outcomes, in terms of developed knowledge, skills and 
IJEBR

26,5

948

attitudes. These links between events and learning were later harvested for comparison in step 3 by coding the transcribed text. Each interview lasted around 45-60 min and was recorded and transcribed verbatim.

4.2.3 Step 3: Analyse the collected data. All of the data transcribed from interviews was analysed with the support of the NVIVO interview coding software. Open coding and axial coding were applied (see Corbin and Strauss, 1990, p. 98). Two coding frameworks were applied [9], one for emotional learning events and one for the resulting effects of interest (see Table 3). The emotional learning events coding framework was based on a framework constructed by Arpiainen et al. (2013). The effects framework was inspired by a framework for entrepreneurial competencies constructed by Fisher et al. (2008).

The open-coding procedure led to the addition of two important effects alongside entrepreneurial competencies. Many instances of increased student motivation and passion were observed as a consequence of entrepreneurial education, as early as in the first wave of interviews. This effect type was thus added to the effects coding framework. Students also frequently said that they learned curricular content in more depth as a consequence of emotional learning events. This effect type was also added to the coding framework for effects appearing in the first wave.

Once all interviews had been coded, tables were generated to enable comparative analysis, such as app reports per metadata tag, common emotional learning events, common developed competencies, other effects of interest and common links between emotional learning events and developed competencies. While these tables gave a general overview of data and causal links within it, they did not replace in-depth qualitative comparative analysis of patterns and mechanisms, or a search for generalisable insights. They were merely the entry point for deeper analysis. Therefore, all generated tables informed a subsequent phase of thematic comparative analysis.

A pattern analysis method that was used was to search for causal mechanisms in the data by using a "matrix coding query" function, available in the NVIVO software package (cf. Hutchison et al., 2010). The resulting matrix table showed, in condensed form, the prevalence and frequency of causal links in the interview data between emotional learning events and effects on students.

Similarities and differences between the three pedagogical approaches were identified and quantified by comparatively analysing the coding frequency of important topics being mentioned in interviews. All interviews were based on emotional learning events and all respondents were asked, in a similar and structured way, about their most important emotional learning events and what they learned from them. Such a structured interview approach facilitates a comparison of differences in experience and effects on respondents. Further, since all interview respondents were chosen for inclusion based on the most relevant emotional learning events found among all participants in each learning environment, these reported differences should extrapolate to the entire population in each setting. Thus, not only is the presence of a key topic in interviews important and illustrative in the comparison, but its absence is too.

\section{Findings}

Through the "matrix coding query" procedure in NVIVO, around 700 link types were identified between 23 emotional learning event types and 32 different types of effects on students. Many links were rare while some were more frequent. By way of illustration, the resulting NVIVO coding matrix for study wave 6 is shown in Table 3 . Each cell in Table 3 indicates the number of links found in the interview data, between an emotional learning event and a corresponding effect. Further, each of the 16,436 links in study wave 6 was associated with qualitative interview data, in which a respondent talked about something 


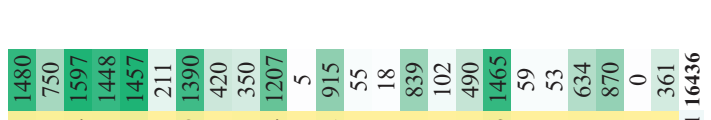

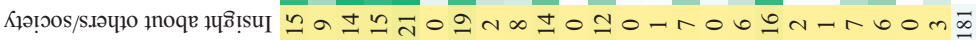

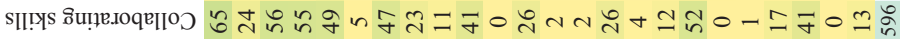

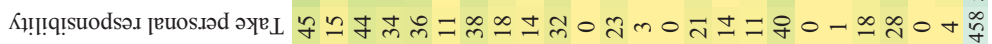
SII!YS KPMS $+-n+m \circ 6$ n m n

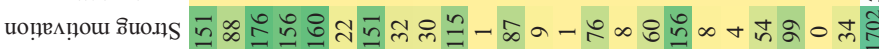

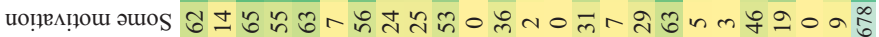

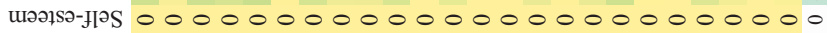

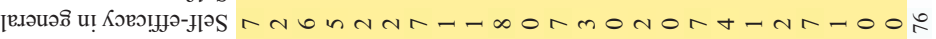

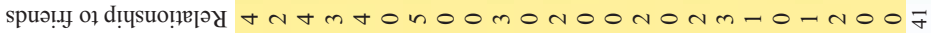

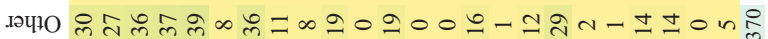

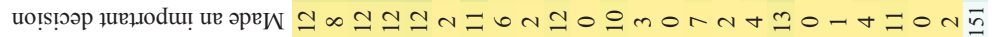

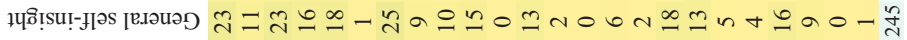

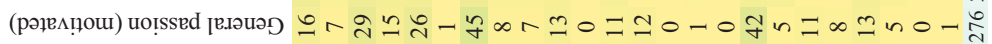

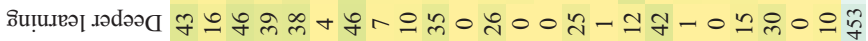

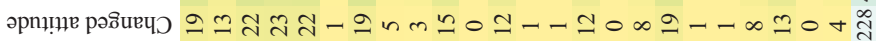

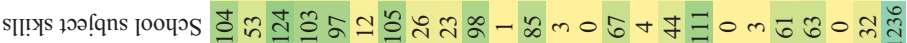

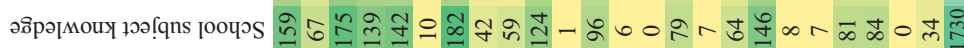

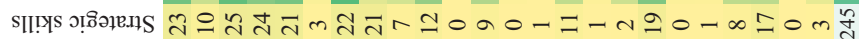

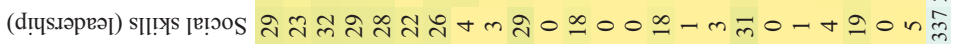

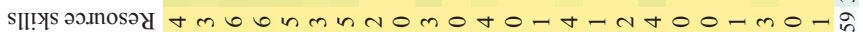

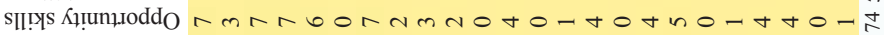

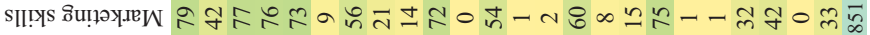

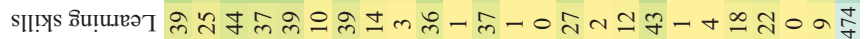

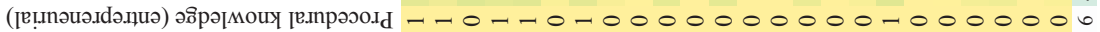

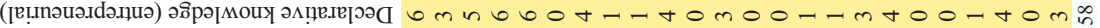
ᄀน

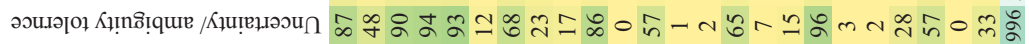

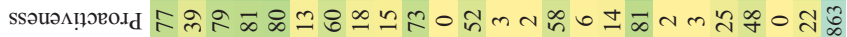
әоиенләнд

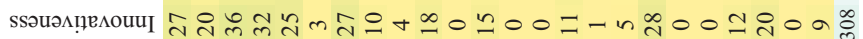

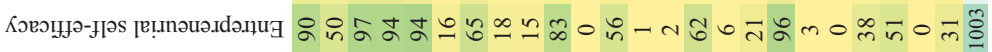

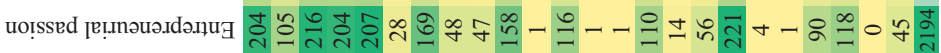

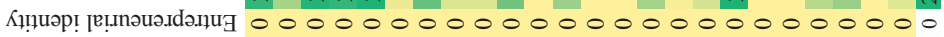

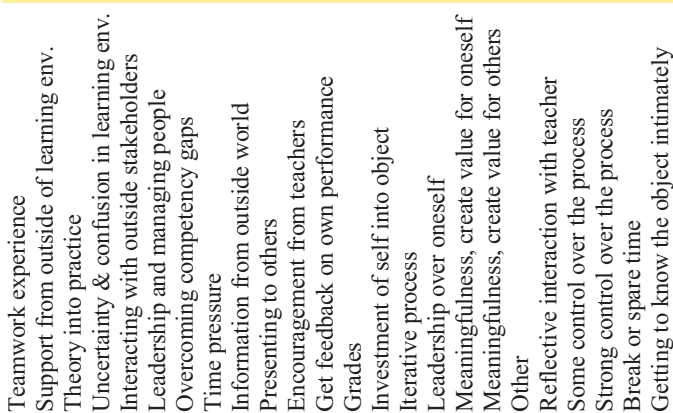

Entrepreneurship in education

949

Table 3.

NVIVO coding matrix for study wave 6 , showing number of links between emotional learning events (left) and student learning outcomes (top) 
IJEBR

26,5

950 that was later coded with one or more emotional learning events as well as one or more effects of interest here. Table 3 also shows that the most frequent causal link found in study wave 6 was between the emotional learning event "Interaction with outside world" and the effect "Entrepreneurial passion", with 221 coded links in the 76 interviews.

The links between emotional learning events and effects on students in the interview data indicate potentially interesting patterns of causal mechanisms. Twelve such links are shown in more detail in Table 4. Two important emotional learning event types were found to be "Interaction with outside world" and "Value creation for others". These were linked to many of the most wanted effects in entrepreneurial education, such as entrepreneurial self-efficacy, proactiveness, marketing skills, entrepreneurial passion and also, at times, entrepreneurial identity.

Entrepreneurial passion [10] played a central role in many of the causal mechanisms that produced the effects being probed for. Antecedents to entrepreneurial passion were: value creation for others (364 links), teamwork (346 links), interaction with outside world (307 links) and feedback and support from external stakeholders (231 links). In the interviews, entrepreneurial passion was also strongly linked to other coded effects, such as: strong motivation to learn in school, increased entrepreneurial self-efficacy, increased responsibility towards self and others and deeply personal development such as changed attitudes, increased perseverance and self-insight (see quotes in Table 4).

A more in-depth account of the findings will now be reported, wave-by-wave on an aggregate level and illustrated by a selection of quotes. More detailed empirical data and analysis are also available in Swedish or English for five of the six waves (see Supplementary material).

\subsection{Findings wave by wave}

The first wave of data collection showed strong effects of full-VeCP on higher education students' entrepreneurial competencies and engagement. Table 4 shows effects frequently mentioned in the interview data to be: entrepreneurial self-efficacy, marketing skills, entrepreneurial passion, motivation, entrepreneurial identity, self-insight, uncertainty tolerance and perseverance. The ability of an emotion-based assessment methodology to uncover micro-level causal mechanisms was also confirmed. A key causal mechanism uncovered was that letting students interact with external stakeholders to create something of substantial value to them triggered not only a strong development of entrepreneurial selfefficacy but also passion and sometimes even identity. A student in biotech entrepreneurship explained:

We had a meeting with a hospital manager. He said, "OK, I know what you do, it's fantastic, I need your instrument, I'd love to work with you". (. . .) It was high-on-life there for a while, I can tell you. Experiencing that people take you seriously. People no longer see you as a student. I think it's cool to feel that they actually listen to us. I think it gives self-confidence, I'd say. I've found this small area where I know things. We trust our own ability more now. (VeCP site 1)

Informed by the first wave, the second wave focused on two compulsory schools using $\mathrm{VaCP}$ by letting students produce and broadcast a one-hour radio programme. The students' production phase involved numerous external stakeholder interactions, through interviews and sponsorship recruitment. The radio programme was also expected to be perceived as valuable to a broad audience in the region. Even if venture creation was absent, similar causal mechanisms to those found in wave 1 were also present (see Table 4). A student explained:

Some things in school do not feel so serious. I've taken this quite seriously because it's radio and everything. It's not just for us in the class to see and hear, but it's for others, externals, too. Then if it's a hundred, or a thousand, or a million, it does not matter. It's still others than the class. (VaCP site 2) 
Entrepreneurship in education
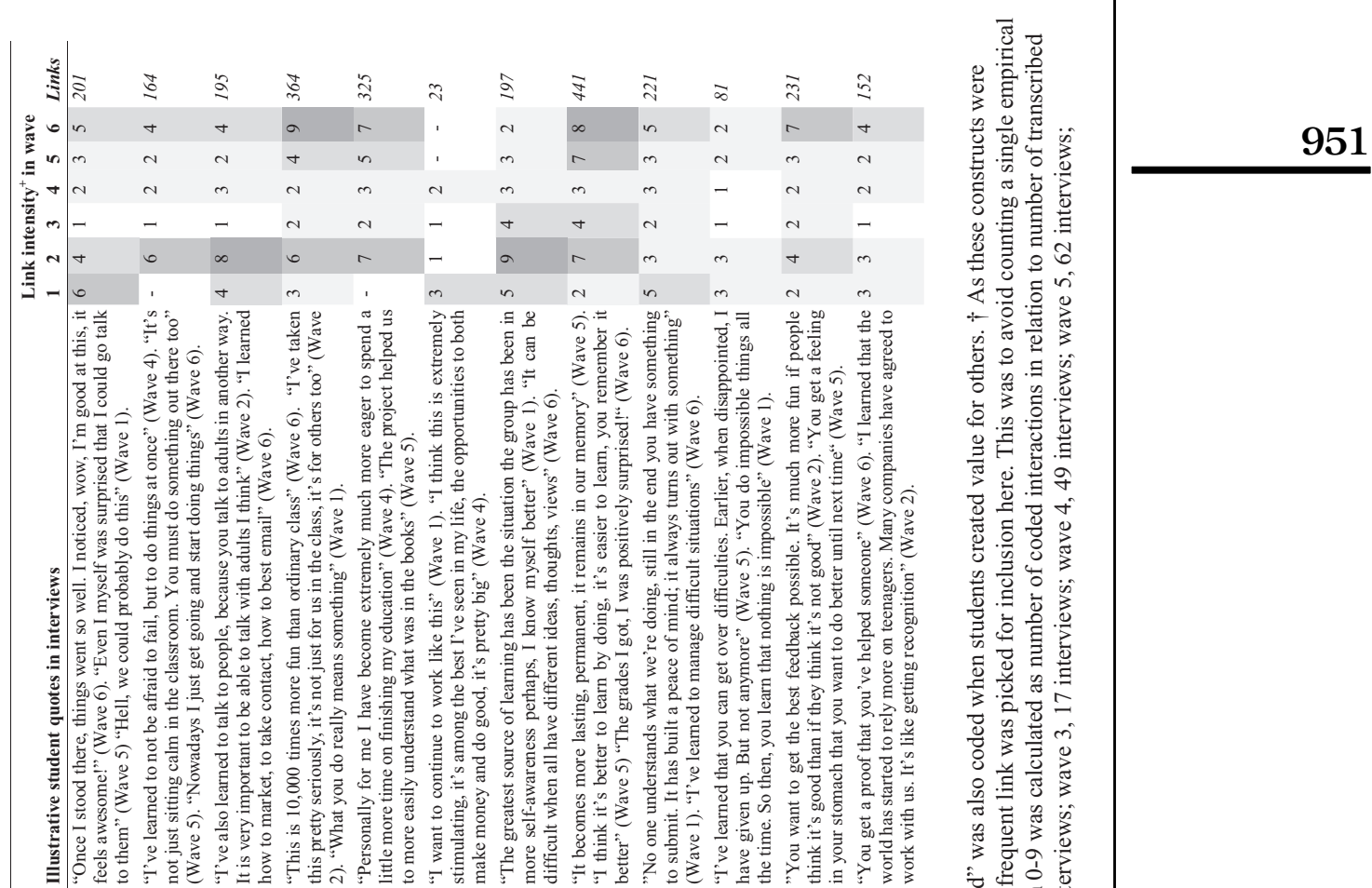

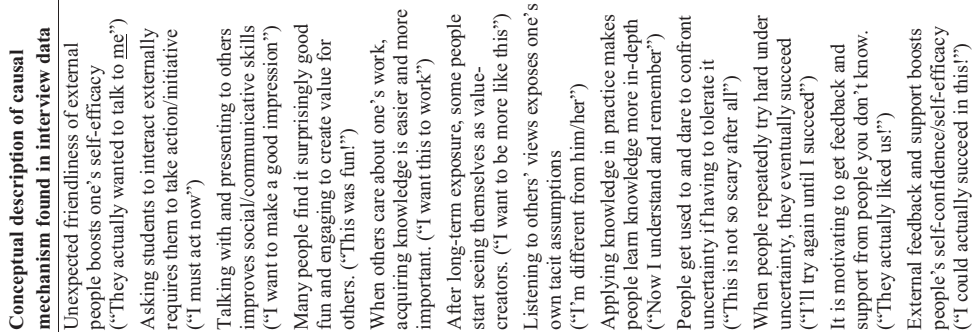

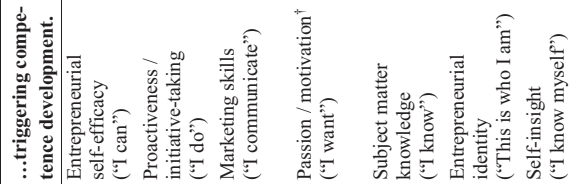

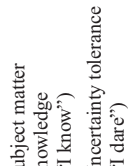

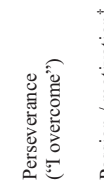

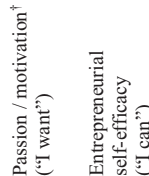
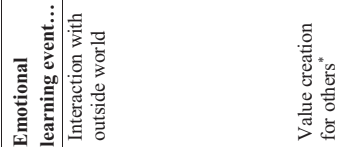

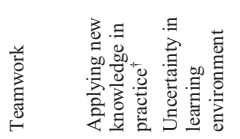

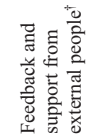

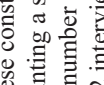

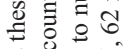

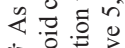

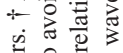

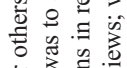

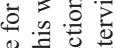

寻苛

管这离

ఫ्ञ

ปั

节寻岁 क

过

记总言

类要

范芯壱

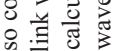

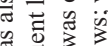

पै

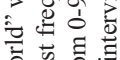

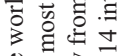

㻤 穿

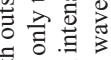

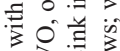

출

总之+

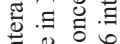

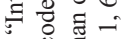

की 0 :

藏苛

उ 클.

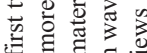

포율

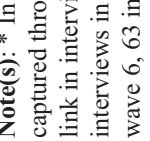

Table 4

Main causal links

uncovered in the interview material in the six waves 
IJEBR

26,5

952

The interview coding in wave 2 also showed that value creation for others can trigger the development of subject matter knowledge (see link intensity for wave 2 in Table 4). When students get to apply new knowledge in value-creation practice, they understand and remember it better.

The third wave was an attempt to study whether the mechanisms found in waves 1-2 were also more broadly present in compulsory education, when teachers had worked with entrepreneurial education. Three schools deemed success cases from three leading support actors in entrepreneurial education were chosen for study. In these schools, the chosen pedagogical approach was IACP, as this is the Swedish policy strategy for entrepreneurial education (Hoppe et al., 2017). The classroom practices were primarily traditional, but also included the occasional thematic group work and study visit outside school. However, the third wave was largely a disappointment in terms of the effects on students' entrepreneurial competencies and motivation (see the low coding intensity for wave 3 in Table 4). Only a few exceptions were found in which students developed some level of entrepreneurial competencies. While many students were generally appreciative of the variation offered by IACP, one student summarised the situation in an app report:

That we are going to build those spaceships and skip a lot of good lessons is really bad! (IACP site 5)

The fourth wave involved a comparison between four concept suppliers in entrepreneurial education, focusing on $\mathrm{VeCP}$ and $\mathrm{VaCP}$ in upper secondary, higher and adult education, plus three different schools using IACP in compulsory education (according to the state-financed teacher training received in entrepreneurial education). Results from waves 1-3 were corroborated. VaCP and VeCP led to strong development of entrepreneurial competencies and student motivation, while IACP had weak if any effect on the development of student entrepreneurial competencies and motivation. Coding intensity was therefore somewhere between that seen in previous waves (see Table 4). VaCP and VeCP had many coded links, whereas IACP had few.

The fifth wave was undertaken through an EU project initiated by a municipality wanting to build upon the promising findings around $\mathrm{VaCP}$ from previous waves. Two schools in Sweden and Turkey received training in $\mathrm{VaCP}$ for two consecutive years and one school participated with a mini-VeCP-based approach provided by the regional branch of Young Enterprise Norway. The study showed that, in terms of triggering student engagement and developing entrepreneurial competencies, $\mathrm{VaCP}$ may be as powerful, or perhaps even more so, than mini-VeCP. It also illustrated strong connections between $\mathrm{VaCP}$ and deeper learning of curriculum knowledge and skills (see the high coding intensity for wave 5 in Table 4). A student in Turkey explained:

Actually, I realise what I have. I possess so much knowledge, but I do not think about it. It's like I did not know it. For example, I have learned something, I forget that I know it, but when someone asks something about it, I remember it again. Suddenly it comes up. (VaCP site 16)

The sixth and final wave was an attempt to corroborate the small-scale findings around VaCP from previous waves, but on a broader scale. Eighteen of the 19 participating schools used $\mathrm{VaCP}$. Some were given training in $\mathrm{VaCP}$, while others were already working with $\mathrm{VaCP}$ for other reasons. In some cases, the effects on students were among the strongest found among all six waves. Two students and a teacher said:

I will never forget this. I will remember it for my whole life. This feels like the best school ever. (Student at VaCP site 28)

I had never thought that so many in my class could succeed with so much. It was really cool to see how huge it could become. I never thought that I could manage as much technology as I did. (Student at $\mathrm{VaCP}$ site 23) 
I get a lot for free. I never need to say why what we do is important; they understand that it is important. You win a lot and the enthusiasm is gigantic! And I save a lot of planning time. Now I plan together with my students. (Teacher at VaCP site 33)

Acting on the task of creating something of value to external people made students passionate about creating value and triggered a strong desire to: learn more, put more energy into schoolwork, take responsibility for oneself and others, to own the learning process to a greater extent and learn knowledge and skills in more depth (see Table 4). There were also many cases of students and teachers being fully convinced that VaCP results in higher grades for many students, due to the increase in student engagement and perceived meaningfulness of schoolwork. Two teachers said:

If they're engaged and motivated the effect is that they learn more too, that's my experience. (VaCP site 34)

Yes, it's been a huge difference. Above all, every student has now passed. Earlier I had five to seven who did not pass in either subjects, but now all are up there. (VaCP site 33)

$\mathrm{VaCP}$ also had the unexpected effect of leading to a better social climate within classes and fewer conflicts between students; thus relieving the teacher of time-consuming conflictmanagement issues. A teacher explained:

It's quite difficult to go out and be mean to someone out there and then you are supposed to go inside and write a diary together five minutes later. There are far fewer conflicts in this group than I have experienced in previous groups.(VaCP site 34)

\subsection{Differences between IACP, $\mathrm{VaCP}$ and $\mathrm{VeCP}$}

The outcome of the coding frequency analysis is shown in Table 5, illustrating salient differences found between the three pedagogical approaches.

The most salient difference was found in students' developed entrepreneurial competencies [11]. The $\mathrm{VaCP}$ and $\mathrm{VeCP}$ interviews had many examples of strong development of students' entrepreneurial competencies, whereas IACP interviews did not. Link analysis showed that two event types accounted for much of this difference: "Interaction with outside world" and "Value creation for others". These two event types were common in VaCP and VeCP, but rare in IACP. This might largely explain why IACP did not affect students so much in this regard.

The second most salient difference was found in levels of engagement and motivation, coded as entrepreneurial passion and general passion/motivation. Here, the coding frequency percentage figures in Table 5 do not fully reflect the differences in engagement and motivation between the three pedagogical approaches. According to the interview respondents, this is because general passion is not felt as strongly as entrepreneurial passion. $\mathrm{VaCP}$ and $\mathrm{VeCP}$ both showed a strong increase in engagement and motivation among participating students, whereas IACP showed only some increase (see quotes on passion in Table 5). Interviews revealed that VeCP triggered strong engagement, primarily by being about real-life entrepreneurship, in terms of starting a company, earning real money and trying to create a profitable business. VaCP did not rely on economic value to trigger engagement at all. Rather, it achieved strong effects through the power of students' passion for making a real-life difference to others and to society at large. IACP triggered some engagement, primarily through the inherent pleasure in pedagogical variation of the everyday school experience, in the joy of learning and joy of working with school subjects. Thus, according to the interviewees (see quotes in Table 5), there was a similarity in effect but a difference in how it was produced. 


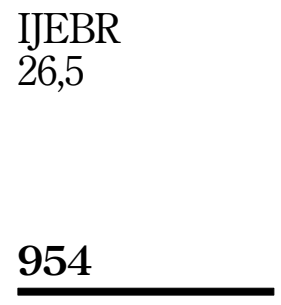

Table 5.

Nine salient differences between the three approaches in terms of impact on various outcome variables coded in the interviews

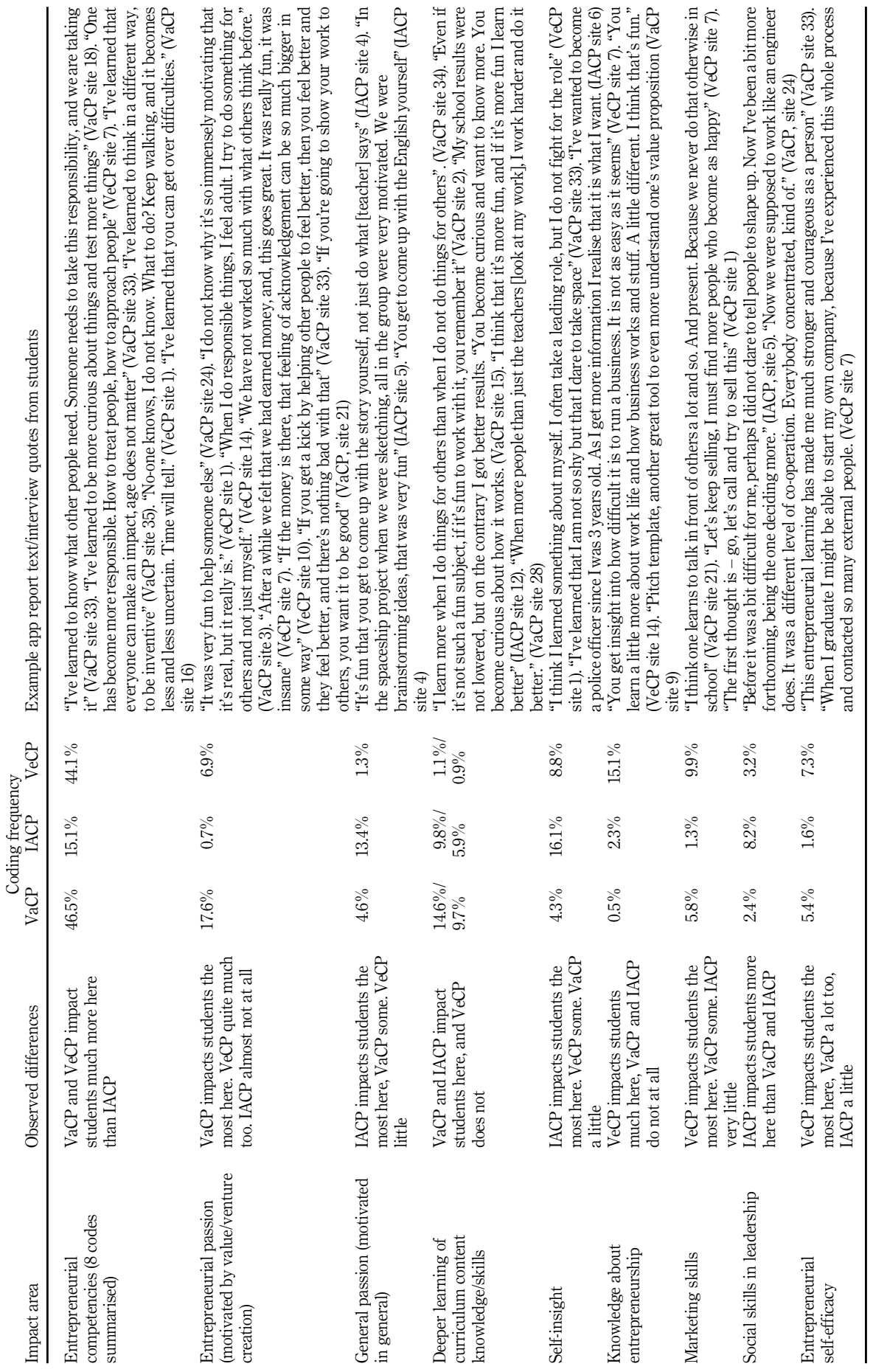


The third most salient difference was found in the effects on students' deeper learning of curriculum content, knowledge and skills. VaCP showed the strongest effects, followed by IACP. Apart from entrepreneurship as a subject, VeCP did not make students learn the curriculum content, knowledge and skills in more depth. According to the students who experienced $\mathrm{VaCP}$ and IACP, it was the increase in engagement levels among students that made them work harder, pay more attention and learn in more depth than they otherwise would have. This causal mechanism was corroborated by the teacher interviews. On many of the VaCP sites, students said that they had worked harder in school than they ever had before. They reported transformative, deeply emotional experiences that changed their perspectives on many aspects of life; experiences they would remember for the rest of their lives. They said that, as a result, they had gained deeper knowledge and skills in maths, languages, social sciences, natural sciences and other core subjects.

\subsection{Challenges found with the three pedagogical approaches}

Challenges of the three different pedagogical approaches also surfaced from the data. When it comes to IACP, many student teams struggled with becoming productive. This was often due to a lack of engagement among certain students within a team. Some had difficulty understanding the purpose of, and seeing the connection between, theory and practice. One student said:

First, I understood kind of nothing; why are we doing this? But then I understood more (. . .) Then the teacher suddenly said, "well, now we're going to build our spaceships". Then we did not understand anything; why the fact-gathering assignment and the spaceship had any connection whatsoever. (site 5)

For VaCP, some subjects were found to be more difficult to work with than others, especially natural science. Some teachers also mentioned that VaCP necessitates collaboration across subjects, making it challenging for a single teacher to work with $\mathrm{VaCP}$ in isolation. Some teachers also said that $\mathrm{VaCP}$ demands more from both teacher and students. Teachers lose some sense of control over the class and students lose some of the emotional security coming from doing things in a very similar and routinised way. A teacher explained:

I think that the main challenge has been to un-schoolify the students a bit. They do not have to sit in their seats and do what the teacher tells them to do, but sometimes they can actually come up with their own ideas, and it's okay to be creative. Give students that responsibility, kind of. (site 33)

Data from the VeCP sites confirmed a previously articulated challenge, stemming from a strong focus of $\mathrm{VeCP}$ on economic value-creation and capitalist values (Johannisson, 2010; Leffler, 2009). In the past, this focus has made it difficult to embed VeCP into non-business subjects (Handscombe et al., 2008; Komulainen et al., 2011; Korhonen et al., 2012; Smith et al., 2006). The current study adds empirical evidence showing in more detail how and why VeCP is unable to integrate well into non-business subjects. VeCP's focus on making money (see quotes in Table 4), rather than on applying curricular knowledge and skills, makes it less effective in strengthening student learning of core curricular knowledge and skills.

The data also illustrated that taking the step from IACP to VaCP can be straightforward in many cases (cf. Figure 1). In particular, wave 3 showed that many examples of IACP could have been transformed relatively easily into a more impactful VaCP-based practice. This could be done by simply adding an opportunity for students to use their knowledge and skills to interact with people outside their own group, class or school and to try and create some value for them. What students already do and create in class can often be connected to an external audience or recipient, who can get some potential value out of what the students do 
IJEBR

26,5

and what they create. When this is done regularly, it establishes a new culture in class. A teacher explained:

When the value-creation bug gets stuck into me and my students, it is difficult to start up a single piece of work without any one of us raising the question, "who will we be doing this for?" (VaCP, site 27)

\section{6}

\section{Discussion}

This study has resulted in three main answers to the question of what differences there are between IACP, VaCP and VeCP in terms of their effects on students. Strong differences were observed in how much entrepreneurial competencies were developed among students, how much students' motivation increased and how much curricular knowledge and skills were developed.

The effects of IACP and VeCP reported here are largely in line with previous research in entrepreneurial education. IACP has recently been summarised as illustrating a "relative (un)effectiveness" due to fuzziness and confusion among teachers (Pepin and St-Jean, 2018, p. 276). By contrast, VeCP approaches have recently been summarised to "typically obtain higher impact", since students are working with "real-life entrepreneurial situations" (Nabi et al., 2017, pp. 288-292). The strong difference in effects on students between IACP and $\mathrm{VeCP}$ found here confirms that there is a need to distinguish between different pedagogical approaches in comparative studies, in order to avoid contradictory findings (Nabi et al., 2017). This is the case with both traditional versus experiential pedagogy, as previously shown by Kozlinska (2016) and between different experiential approaches, as shown here.

While this study is one of the first in entrepreneurial education to compare the differing effects across different pedagogical approaches, there have been other comparative studies in general education. The relatively weak effects of IACP on the development of curricular knowledge and skills may be mirrored in the small effects that Hattie (2008) and Dochy et al. (2003) found for problem-based learning, as well as the medium effects Hattie (2008) found for cooperative learning [12]. The strong effects of $\mathrm{VaCP}$ on the development of curricular knowledge and skills may be mirrored in the strong effects Hattie (2008) and Celio et al. (2011) found for service-learning and in the strong effects Smith et al. (2014) found for workintegrated learning. Still, caution is needed, since Hattie's compilations have been criticised for being overly positivistic, dogmatic and simplistic (Biesta, 2007; McKnight and Whitburn, 2018). The differences between IACP, VaCP and VeCP are summarised in Table 6.

\subsection{A tentative causal mechanisms scheme: how are strong effects produced?}

Scholars have recently called for assessment research that opens the "black box" of entrepreneurial education (Lans et al., 2017; Maritz and Brown, 2013). Such calls signify a need to go beyond mere "yes/no" answers to whether or not effects are produced, to also illustrate more qualitatively how, when and why effects are produced by entrepreneurial education. Therefore, a qualitative account is given here to summarise the empirical findings of this study. When students get to apply curricular knowledge and skills in teams, creating value for external stakeholders through personal interactions that trigger external feedback and support, they seem to undergo profound development in a variety of sought-after entrepreneurial competencies. Such activities also trigger entrepreneurial passion; this plays a key role in making them work harder, want to learn more, take more responsibility, be kinder to each other and develop on a deeply personal level. This then leads to deeper learning of curricular knowledge and skills, more frequent instances of self-directed learning and fewer conflicts in class. This qualitative summary is illustrated in Figure 4. 


\begin{tabular}{|c|c|c|c|c|}
\hline & $\begin{array}{l}\text { Idea and artefact-creation } \\
\text { pedagogy (IACP) }\end{array}$ & $\begin{array}{l}\text { Value-creation pedagogy } \\
\text { (VaCP) }\end{array}$ & $\begin{array}{l}\text { Venture-creation } \\
\text { pedagogy (VeCP) }\end{array}$ & $\begin{array}{l}\text { Entrepreneurship } \\
\text { in education }\end{array}$ \\
\hline Focus & Idea and artefact-creation & Value creation & Venture creation & \\
\hline Definition & $\begin{array}{l}\text { Let students learn by } \\
\text { working in teams to create } \\
\text { artefacts around ideas they } \\
\text { develop themselves }\end{array}$ & $\begin{array}{l}\text { Let students learn by } \\
\text { applying their knowledge } \\
\text { to create something of value } \\
\text { to external stakeholders }\end{array}$ & $\begin{array}{l}\text { Let students learn } \\
\text { through mini or full- } \\
\text { venture creation }\end{array}$ & 957 \\
\hline $\begin{array}{l}\text { Definitional } \\
\text { grounding and } \\
\text { source of passion }\end{array}$ & $\begin{array}{l}\text { Opportunity identification } \\
\text { and creation (Shane, 2003) }\end{array}$ & $\begin{array}{l}\text { New value creation (Bruyat } \\
\text { and Julien, 2001) }\end{array}$ & $\begin{array}{l}\text { Organisation creation } \\
\text { (Gartner, 1989) }\end{array}$ & \\
\hline $\begin{array}{l}\text { Examples in } \\
\text { practice }\end{array}$ & $\begin{array}{l}\text { Students work thematically } \\
\text { in class } \\
\text { Students create artefacts in } \\
\text { class, such as plans, } \\
\text { presentation materials or } \\
\text { prototypes }\end{array}$ & $\begin{array}{l}\text { Students produce text or } \\
\text { video that is useful or } \\
\text { enjoyable for others } \\
\text { Students help others with } \\
\text { something they need help } \\
\text { with }\end{array}$ & $\begin{array}{l}\text { Students start a new } \\
\text { mini-venture that is later } \\
\text { liquidated } \\
\text { Students start a full-scale } \\
\text { venture that they become } \\
\text { co-founders of if } \\
\text { successful }\end{array}$ & \\
\hline Observed impact & $\begin{array}{l}\text { Weak/no development of } \\
\text { entrepreneurial } \\
\text { competencies } \\
\text { Somewhat increased } \\
\text { motivation } \\
\text { Some development of } \\
\text { curricular knowledge/skills }\end{array}$ & $\begin{array}{l}\text { Strong development of } \\
\text { entrepreneurial } \\
\text { competencies } \\
\text { Strong increase of } \\
\text { motivation } \\
\text { Strong development of } \\
\text { curricular knowledge/skills }\end{array}$ & $\begin{array}{l}\text { Strong development of } \\
\text { entrepreneurial } \\
\text { competencies } \\
\text { Strong increase of } \\
\text { motivation } \\
\text { Weak/no development of } \\
\text { curricular knowledge/ } \\
\text { skills outside } \\
\text { entrepreneurship }\end{array}$ & $\begin{array}{r}\text { Table } 6 . \\
\text { Comparison of three } \\
\text { different approaches in } \\
\text { entrepreneurial } \\
\text { education. A focus on } \\
\text { idea and artefact } \\
\text { creation (IACP) is }\end{array}$ \\
\hline $\begin{array}{l}\text { Motivational } \\
\text { theory base }\end{array}$ & Hedonism & Belonging & Egoism & $\begin{array}{r}\text { creation (IACP) is } \\
\text { compared to a focus on } \\
\text { value creation (VaCP) }\end{array}$ \\
\hline Critical questions & $\begin{array}{l}\text { Is this really } \\
\text { entrepreneurship? }\end{array}$ & $\begin{array}{l}\text { Is this too good to be true? } \\
\text { Is this really that different? }\end{array}$ & Is this really education? & $\begin{array}{l}\text { and on venture } \\
\text { creation (VeCP) }\end{array}$ \\
\hline
\end{tabular}

Figure 4.

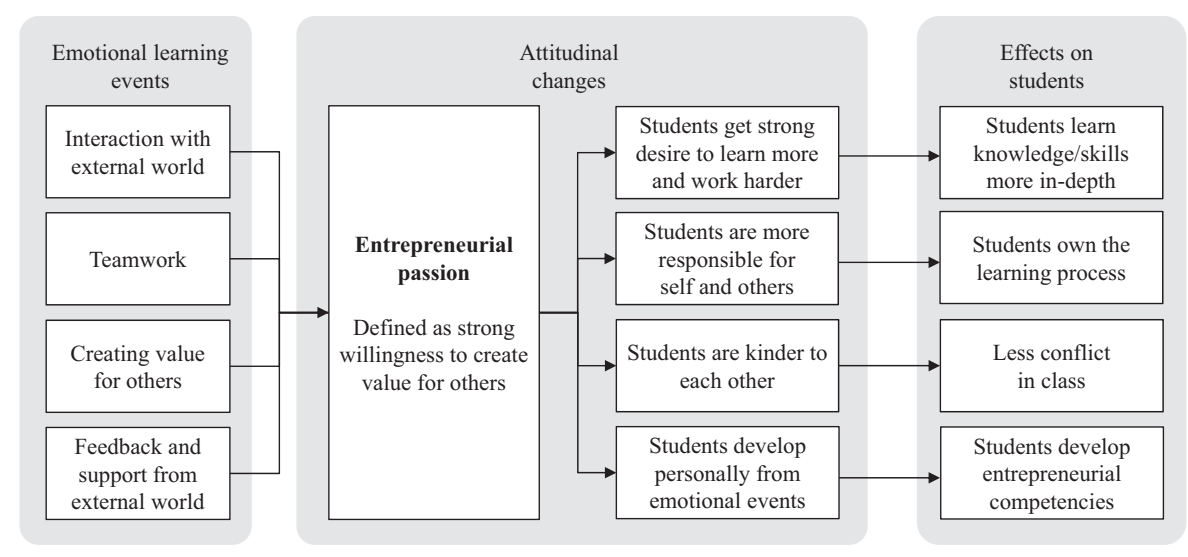

A mechanism scheme illustrating the role of entrepreneurial passion in entrepreneurial education. The model shows how entrepreneurial passion plays a key role in generating strong positive effects in entrepreneurial education. Emotional learning events lead to attitudinal changes which, in turn, produce effects

Figure 4 is an example of a "mechanism scheme"; in other words, an "abstract representation of mechanisms that could bring about effects of a certain kind" (Ylikoski, 2019, pp. 3-4). Such schemes may be seen as middle-range theories (Merton, 1968), in which "theory is a toolbox of different kinds of semi-general mechanisms" (Hedström and Wennberg, 2017, p. 99). 
IJEBR

26,5

958

Compared to the common call for more macro-level randomised control studies (cf. Longva and Foss, 2018; Martin et al., 2013; Rideout and Gray, 2013), the toolbox-of-mechanisms view represents a different way forward for impact assessment of entrepreneurial education. Instead of searching for answers to a simplistic yes/no question, "does entrepreneurial education work?", it represents a search for mechanism-based answers to the question of "how, when and why does entrepreneurial education work?"

A toolbox-of-mechanisms view may also be associated with recent calls for more emotionbased assessment studies (Nabi et al., 2017), since it could provide viable answers to a vexing question: "which emotional events to probe for in future assessment studies?" To illustrate this, a tentative emotional events-centric and mechanism-based proposition (grounded in Table 4 of this study) is articulated here:

Proposition 1. Entrepreneurial education in which students get to experience emotionally charged...

(1) ... interaction with the external world,

(2) ...teamwork,

(3) ...value creation for others and

(4) ... feedback and support from external people

is more effective than other, less emotionally charged entrepreneurial education.

\subsection{A tentative explanatory model: why do effects on students differ?}

The following brief attempt to explore why the three pedagogical approaches lead to differing levels of effects on students draws upon action theory and motivation theory. All three pedagogical approaches compared here involve students taking action to create something. According to von Mises (1949) and Oakeshott (1991), human action is always meaningful and purposeful from the perspective of the person choosing to take action (Callahan, 2005). Further, emotions play a crucial role both in connecting a learning experience to one's own personal meaning (Dirkx, 2001) and in triggering deep learning (Boekaerts, 2010; Jarvis, 2006). Emotion, meaning, learning and purpose are thus interconnected. Different purposes as experienced by students will then lead to different levels of emotionality, meaning and learning.

This study has offered much insight into how students interpret the purpose of educational activities. For many students in this study, the purpose of IACP was unclear and, at times, even devoid of purpose, apart from offering a moment of enjoyment and pleasure. IACP may thus be viewed as anchored in hedonistic motivation theory of searching for pleasure and avoiding pain (Fiske, 2008). Turning to VeCP, for many students, the purpose was self-orientated; centred on making money for themselves, so that their business would become viable. It was thus anchored in egoistic motivation theory (Fiske, 2008). Finally, for many students, the purpose of $\mathrm{VaCP}$ was others-orientated; centred on helping other people. $\mathrm{VaCP}$ thus opens the way to a different motivational theory base for education than the more common self-orientated, hedonistic and egoistic motivational theories so prevalent in classroom research (Fiske, 2008), or the situation of students lacking motivation altogether (Fredricks et al., 2004). Instead, VaCP seems to lean on belongingness and prosocial motivation theory (Fiske, 2008), positing that "we humans can and do act to benefit others" and that "people can do spectacular things for others" (Batson et al., 2008, p. 135). Related to this, Baumeister et al. (2013, p. 516) have shown empirically how perceived meaningfulness is stronger in others-orientated activities than in self-orientated ones, concluding that "the quest for meaning is a key part of what makes us human, and uniquely so". Maybe the others-orientated purpose for students explains why VaCP triggers high levels of positive emotion and motivation, high levels of perceived meaningfulness and deep learning of core curriculum knowledge and skills? 
Relating to literature on entrepreneurial passion (Cardon et al., 2009), these results indicate that an entrepreneurial role identity grounded in value creation for others could merit further study (for example, "creating value for others is an important part of who I am"). The findings reported here indicate that, as a source of entrepreneurial passion, such a value-creating role could be a strong motivational force in entrepreneurial education; perhaps even stronger than the more common inventor or venture founder/developer role identities grounded in opportunity identification and organisation creation definitions of entrepreneurship (cf. Cardon et al., 2009; Miller et al., 2012; Renko, 2013). These different sources of entrepreneurial passion are shown in Table 6.

\subsection{Four critical questions around the three pedagogical approaches}

In this study, IACP and VeCP have been associated with certain limitations in terms of their effects on students. The weak effects of VeCP on curricular knowledge and skills outside entrepreneurship might imply problems of integrating $\mathrm{VeCP}$ with non-business education. This might explain why some teachers are sceptical about VeCP. Economic activity and capitalism are often seen as being misaligned with the overall educational aim of developing curricular knowledge and skills (Johannisson, 2010; Komulainen et al., 2011). Would it not, then, be reasonable for some educators observing $\mathrm{VeCP}$ to ask a critical question: "is this really education?" Is $\mathrm{VeCP}$ then to be considered an effective but marginal approach, of relevance primarily to business students?

One limitation that seems to be associated with IACP is its relatively weak effects in all three areas assessed here. Might this be due, in part, to IACP suffering from a fuzziness caused by definitional dilution (cf. Neck and Corbett, 2018; Hoppe et al., 2017)? Consistent with this, Hägg (2016, p. 14) argues that when "creation of organisations (Gartner, 1989), is taken out of entrepreneurial learning, we are merely left with a version 2.0 of the progressive educational movement." Would it not, then, be reasonable for some entrepreneurs observing IACP to ask a critical question: "is this really entrepreneurship?" Is IACP then to be considered a broadly applicable but fuzzy and inefficient approach to entrepreneurial education?

In this study, VaCP emerges as a third alternative; seemingly capable of bridging between education and entrepreneurship in a more productive way than was previously possible (cf. Figure 1 and Table 6). Can VaCP then allow for the strong effects of VeCP to be reached without the inherent complexity of letting students start a mini or full-venture? And can VaCP help preserve the broad applicability of IACP in most subjects and on all levels of education, without suffering from weak effects and definitional fuzziness? If so, one might hypothesise that the cost/benefit relationship of entrepreneurial education could be greatly improved. Such a bridging perspective resonates with a recent claim by Günzel-Jensen et al. (2017, p. 327), that going from "about/for" pedagogy to experiential "through" pedagogy "may be too big a step for students". They conclude that a new, bridging concept is needed: "learning from" interventions that mimic entrepreneurship.

Still, these considerations are based on emerging empirical evidence. The potentially useful results disclosed here need to be corroborated by other researchers and in other contexts. Value creation for others may also be seen as present in many existing instances of both IACP and VeCP. Would it not, then, be reasonable if people contemplating VaCP asked two critical questions: "is this too good to be true?" and "is this really that different?" The four critical questions are shown in Table 6.

\subsection{Implications for practice}

This study has provided emerging empirical data, showing that VaCP may constitute an escape from the dilemma, for many teachers, of entrepreneurial education being caught between two limiting courses of action. Could it be that teachers no longer need to choose 
IJEBR

26,5

960 between effective but marginal practices and widely applicable but fuzzy and ineffective ones? If so, VaCP may be opening up a new solution space for entrepreneurial education practice.

For IACP practitioners, the necessary step to achieve stronger effects on students is a small one, as this study has shown that IACP can be relatively easily transformed into VaCP. In doing so, teachers need to understand the risk of triggering too much emotionality in students, and the associated need to provide them with emotional support. VaCP also necessitates appropriate teacher training.

\subsection{Implications for policy}

Based on the results reported here, policymakers may be prompted to reconsider some of the ongoing initiatives to infuse entrepreneurship into education. In some cases, VaCP could be a more effective and efficient way forward than IACP or VeCP. For existing activities, it might be worthwhile investigating how $\mathrm{VaCP}$ may be integrated with them, so as to complement and strengthen them.

$\mathrm{VaCP}$ also opens the way to new objectives when infusing entrepreneurship into education. Given the strong effects of $\mathrm{VaCP}$ on the learning of curricular knowledge and skills, initiatives to infuse entrepreneurship into education might now be better able to inject improvements at the heart of education. This might imply that entrepreneurial education no longer needs to rely solely on economic policy objectives, such as economic growth and employability; it might be connected directly to educational policy objectives, such as improving student learning and raising results in various student performance rankings. Such alignment with the core objectives of education could facilitate a broader diffusion of entrepreneurial education.

\subsection{Implications for further research}

Since the effects of IACP and VeCP reported here are largely in line with previous research (cf. Kozlinska, 2016; Pepin, 2012), a key future work for scholars might be to corroborate the results around $\mathrm{VaCP}$ presented in this article. The empirical data were collected by a single research team, using a single mix of methodologies and mostly in a single country. Other research teams may, therefore, want to conduct research into $\mathrm{VaCP}$ using other methods and in other cultures, to see if they find similar effects and causal mechanisms. Such research would be particularly warranted in higher and adult education institutions, since only eight such participants of $\mathrm{VaCP}$ were included in this study. Another area in which the effects of VaCP might be studied is vocational education. This would perhaps be the most natural application of $\mathrm{VaCP}$, as there are numerous examples of programmes and courses, in which students learn by creating value for others as apprentices.

Scholars might also investigate the similarities and differences between $\mathrm{VaCP}$ and other pedagogical approaches often claimed to be similar to entrepreneurial education; for example, problem-based learning, project-based learning and service-learning. Such comparisons have previously been made on a superficial level (cf. Lackéus et al., 2016), but not empirically or in more depth [13]. On a more micro-level, scholars might also conduct impact assessment studies that probe for differences in the prevalence of emotional learning events that have been found to produce outcomes of interest; for example, interaction with the outside world, teamwork, value creation for others and feedback and support from external people.

The emergence of VaCP also poses new semantic challenges. Is "value-creation pedagogy" an appropriate term, or should such practice be subsumed under either of the established terms? And what does the overarching term "entrepreneurial education" signify, when a value-creation perspective is added? 


\section{Conclusions}

This work has posited that $\mathrm{VaCP}$ could be a bridge between the two established pedagogical approaches of IACP and VeCP. Hence, in certain contexts, VaCP might be a way to overcome some of the acknowledged limitations of IACP and VeCP. For certain teachers, this situation may be viewed as being caught between two unpleasant choices. However, another way to view such a dilemma would be as a tradeoff. Weick (1979, p. 35) has emphasised the importance of acknowledging tradeoffs in social science, paraphrasing Thorngate (1976) by stating that "it is impossible for a theory of social behaviour to be simultaneously general, accurate, and simple". Transferred to the topics examined here, is it then impossible for experiential entrepreneurial education to be simultaneously effective, widely applicable and precise? What if a generic and unavoidable aspect of social life were to be that gains made in generalisability and applicability (when going from VeCP to IACP) are lost in precision and effectiveness? If this is the case, then the prospect of finding an escape from such a generic tradeoff, a panacea or magic bullet, might seem slim and unrealistic. Claiming that $\mathrm{VaCP}$ gives stronger effects, wider applicability, higher definitional precision and lower hurdles to implementation and diffusion than previously established approaches might thus be viewed as unrealistic. Indeed, if anyone were to claim to have found such an escape, the level of evidence required to accept and trust such a statement would have to be high.

Thus, interpreting the large volumes of empirical data on the three pedagogical approaches compared here needs to be approached with significant caution and a critical stance. The findings give such a positive image of $\mathrm{VaCP}$ that one inevitably needs to question whether they are simply too good to be true, or whether differences between the three pedagogical approaches have been exaggerated. Questions need to be posed by outsiders concerning whether study cases have been selected reasonably, whether the data collection has been trustworthy, whether the research team has interpreted that data appropriately and whether the methodology applied was robust and fit for purpose. It is thus important to consider the risk of overstating the results. Methodological caveats in the present study might include unexpected effects of self-selection bias, challenges in comparing across different education levels and hidden errors stemming from unaccounted contextual dimensions. Another limitation relates to differences in the enactment of different pedagogical approaches, caused, for example, by differences in teachers' prior experience or training. There might be instances of IACP out there that produce much stronger effects than have been found in the cases investigated here. Instances of $\mathrm{VeCP}$ might also exist which scale well across an entire educational institution and which strengthen students' learning of non-business knowledge and skills.

Notwithstanding the numerous methodological and semantical challenges, this study has shown some emotional learning events to be more impactful on students than others, such as interaction with the outside world and value creation for others. This might explain why some teachers and programmes succeed better than others in entrepreneurial education. With pedagogical differences being more substantial than previously assumed in entrepreneurial education, it may, perhaps, be more worthwhile to conduct further study of the particularly successful teachers and particularly emotionally charged programmes (investigating "When, how and why is entrepreneurial education working?" cf. Brentnall et al., 2018) than of average teachers and programmes (investigating "Does entrepreneurial education work?”, cf. Bae et al., 2014; Martin et al., 2013). Such research might be a pathway towards stronger effects and broader relevance of entrepreneurial education.

\section{Notes}

1. In this article, the term "pedagogy" is defined as theories and models of teaching and learning. This is in keeping with the Anglo-American educational research tradition and thus covers both "pedagogy" and "didactics", which are commonly used terms in Continental approaches (cf. Kyrö, 2005).
Entrepreneurship in education 
IJEBR

26,5

\section{2}

2. Neoliberalism is a political ideology that celebrates market mechanisms through privatisation, competition through the exercise of "freedom of choice" and a reliance on self-sufficient, enterprising and self-optimising individuals (Castree, 2010). The challenges of neoliberalism include increased gender, class and race inequality, a neglect of democratic values and an unjust blame of the poor for their misfortunes (Gill, 2014).

3. The typology was created abductively over a period of seven years. An abductive research approach implies a simultaneous development of theoretical framework, empirical fieldwork and case analysis, see Dubois and Gadde (2002). The abductive process has been detailed in the methodology section of a doctoral thesis (Lackéus, 2016, pp. 36-46).

4. Notwithstanding other differences, the factor used in this research to distinguish between mini and full-VeCP is whether or not students are expected to incorporate their venture if it proves successful. Thus, what is deemed "mini" is students not being expected, encouraged or even allowed to continue their venture post-graduation.

5. Wave 1 in Table 1 comprised site 1 , wave 2 comprised sites $2-3$, wave 3 comprised sites $4-6$, wave 4 comprised sites 7-13, wave 5 comprised sites 14-16 and wave 6 comprised sites 17-35.

6. According to Wikipedia, the average age span of compulsory education in the world is $6-16$, see https://en.wikipedia.org/wiki/Compulsory_education\#Per-country_variations_in_the_age_ range_of_compulsory_education

7. The term "learning environment" is used here to signify a formal learning environment, in which a teacher dictates a learning process for multiple students in a predetermined way. It could be a course, a programme or part of compulsory schooling.

8. For more information on the smartphone app and its different uses in practice and research, see www.loopme.io.

9. The coding frameworks were first used in wave 1 , and then abductively developed further in each subsequent wave through open coding. The final version of the two coding frameworks is shown in Table 3. All key concepts shown in the first two columns of Table 4, except for "Value creation for others", were coded in all waves and thus formed part of all coding frameworks from the start.

10. Defined as passion for new value creation (cf. Bruyat, 1993).

11. Eight codes were used to capture entrepreneurial competencies as a composite construct: entrepreneurial passion, entrepreneurial identity, entrepreneurial self-efficacy, general self-efficacy, uncertainty and ambiguity tolerance, proactiveness, marketing skills and opportunity skills.

12. Hattie claims that an effect size below 0.20 is small, between 0.30 and 0.60 is medium, and above 0.60 is strong. Problem-based learning has an effect size of 0.26 , cooperative learning 0.42 and servicelearning 0.58 (see Hattie, 2017).

13. While the purpose of this article is not to compare entrepreneurial education to other pedagogical approaches, some speculation will nevertheless be provided here to inspire future research. Three novel and unique contributions of $\mathrm{VaCP}$ could be: (1) its broad applicability in general education, well beyond, say, vocational education; (2) its reliance on entrepreneurship as a practice grounded in expertise, traditions and prescriptive methods; and (3) its emphasis on novel value created, as opposed to the routine value creation often seen in vocational education. An interesting comparison might be to study $\mathrm{VaCP}$ alongside service-learning, apprenticeship education, internships and other types of experiential and socially situated learning approaches, in which students learn by creating value for others.

\section{Acknowledgments}

The author would like to express his deepest gratitude to the many people who contributed to this research. The article is based on six different waves of data collection and analysis that involved a large number of people over five years. Carin Sävetun at Framtidsfrön/Chalmers University of Technology/Me Analytics AB managed the app deployment and data collection 
process and did most of the interviews in study waves $2-6$. She also played a key part in the analysis of data from study waves 2-6 and co-authored the internal reports for study waves 2 , 3, 4 and 6. The interviews in Malmö, for study wave 4, were done by Annhild Månsson at Gimle AB. The interviews in Turkey, in study wave 5, were done by Tuba Kinali, Zeynep Kaya and Fredrik Johansen. Interview transcription was done by the author, Carin Sävetun, Ewa-Lena Lackéus and a number of transcription consultants. The mobile app-based data collection instrument Loopme was built by programmers Senad Santic, Michael Jasinski, Hesho Rashid, Carl Rynning, Martin Helmersson, Patrik Bäckström, Patrik Nygren, Christoffer Henriksson and Dionysios Papathanopoulos at Me Analytics AB. The functionality of the app instrument was specified and tested by the author and Carin Sävetun, Christer Westlund, Senad Santic, Michael Jasinski at Me Analytics AB and design consultant Lars Gäfvert. The scientific process was supervised and supported by $\mathrm{PhD}$ supervisors Karen Williams Middleton and Mats Lundqvist at Chalmers University of Technology and $\mathrm{PhD}$ examiner Flemming Norrgren. The case selection process in study wave 3 was supported by Christer Westlund at Me Analytics AB and Ragnar Asbrink at the Swedish National Agency of Education (SNAE). SNAE's participation in study waves 3 and 6 was championed and coordinated by Ragnar Asbrink. Analysis of findings was supported by Malin Heimer Nilsson and Viktoria Struxsjö, among others. The resulting article was reviewed by six anonymous reviewers and the two editors Helle Neergaard and Ulla Hytti. The studies drawn upon here were also conducted in collaboration with, and financed by, a large number of organisations. Study wave 1 was conducted in collaboration with the University of Gothenburg and was financed by Chalmers University of Technology. Study wave 2 was conducted in collaboration with Framtidsfrön and the municipalities of Kungsbacka and Härryda and was financed by Business Region Göteborg, Västra Götalandsregionen and Chalmers University of Technology. Study wave 3 was conducted in collaboration with $\mathrm{Me}$ Analytics $\mathrm{AB}$ and financed by SNAE plus three different municipalities. Study wave 4 was conducted in collaboration with Ung Företagsamhet (Young Enterprise), Stiftelsen Drivhuset, Lund University (Venture Lab), Me Analytics AB and the municipalities of Skurup, Lerum and Landskrona and was financed by Region Skåne and the participating municipalities. Study wave 5 was conducted in collaboration with Göteborgs Stad, Esenyurt Halk Egitim Mudurlugu, Mustafa Yesil Ortaokulu, Ungt Entreprenørskap, Chalmers University of Technology, Rakkestad Ungdomsskole and Me Analytics $\mathrm{AB}$ and was financed by the European Union through their Erasmus Plus programme. Study wave 6 was conducted in collaboration with, and financed by, SNAE and the municipalities of Sundsvall, Varberg, Kungsbacka, Göteborg, Växjö, Nacka, Huddinge and Skövde.

\section{References}

Aadland, T. and Aaboen, L. (2018), "Systematising higher education: a typology of entrepreneurship education", in Hytti, U., Blackburn, R. and Laveren, E. (Eds), Entrepreneurship, Innovation and Education: Frontiers in European Entrepreneurship Research, Edward Elgar, Cheltenham.

Arpiainen, R.-L., Lackéus, M., Täks, M. and Tynjälä, P. (2013), “The sources and dynamics of emotions in entrepreneurship education", Trames, Vol. 17 No. 4, pp. 331-346.

Bacigalupo, M., Kampylis, P., Punie, Y. and Van den Brande, G. (2016), EntreComp: The Entrepreneurship Competence Framework, Publication Office of the European Union, Luxembourg.

Bae, T.J., Qian, S., Miao, C. and Fiet, J.O. (2014), “The relationship between entrepreneurship education and entrepreneurial intentions: a meta-analytic review", Entrepreneurship: Theory and Practice, Vol. 38 No. 2, pp. 217-254.

Ball, S.J. (2013), The Education Debate, Policy Press, Bristol. 
IJEBR

26,5

\section{4}

Barr, S.H., Baker, T. and Markham, S.K. (2009), "Bridging the valley of death: lessons learned from 14 Years of commercialization of technology education", The Academy of Management Learning and Education, Vol. 8 No. 3, pp. 370-388.

Barrett, W. (1979), The Illusion of Technique: A Search for Meaning in a Technological Civilization, Anchor Press/Doubleday, New York.

Batson, C.D., Ahmad, N., Powell, A.A. and Stocks, E. (2008), "Prosocial motivation", in Shah, J. and Gardner, W. (Eds), Handbook of Motivation Science, Guilford Publications, New York, pp. 135-149.

Baumeister, R.F., Vohs, K.D., Aaker, J.L. and Garbinsky, E.N. (2013), "Some key differences between a happy life and a meaningful life", The Journal of Positive Psychology, Vol. 8 No. 6, pp. 505-516.

Berglund, K. (2013), "Fighting against all odds: entrepreneurship education as employability training", Ephemera, Vol. 13 No. 4, pp. 717-735.

Biesta, G. (2007), "Why "what works" won't work: evidence-based practice and the democratic deficit in educational research", Educational Theory, Vol. 57 No. 1, pp. 1-22.

Biesta, G. (2009), "Good education in an age of measurement: on the need to reconnect with the question of purpose in education", Educational Assessment, Evaluation and Accountability, Vol. 21 No. 1, pp. 33-46.

Biggs, J.B. and Tang, C. (2011), Teaching for Quality Learning at University: What the Student Does, 4th ed., McGraw-Hill Education, New York, NY.

Blenker, P., Korsgaard, S., Neergaard, H. and Thrane, C. (2011), "The questions we care about: paradigms and progression in entrepreneurship education", Industry and Higher Education, Vol. 25 No. 6, pp. 417-427.

Blumenfeld, P.C., Soloway, E., Marx, R.W., Krajcik, J.S., Guzdial, M. and Palincsar, A. (1991), "Motivating project-based learning: sustaining the doing, supporting the learning", Educational Psychologist, Vol. 26 Nos 3-4, pp. 369-398.

Boekaerts, M. (2010), "The crucial role of motivation and emotion in classroom learning", in Dumont, H., Istance, D. and Benavides, F. (Eds), The Nature of Learning, OECD Publishing, Paris, pp. 91-111.

Brentnall, C., Rodríguez, I.D. and Culkin, N. (2018), "The contribution of realist evaluation to critical analysis of the effectiveness of entrepreneurship education competitions", Industry and Higher Education, 0950422218807499.

Breslin, D. and Jones, C. (2014), "Developing an evolutionary/ecological approach in enterprise education”, International Journal of Management in Education, Vol. 12 No. 3, pp. 433-444.

Bruyat, C. (1993), “Création d'entreprise: contributions épistémologiques et modélisation”, Doctoral thesis, Université Pierre Mendès-France-Grenoble II.

Bruyat, C. and Julien, P.-A. (2001), "Defining the field of research in entrepreneurship", Journal of Business Venturing, Vol. 16 No. 2, pp. 165-180.

Callahan, G. (2005), "Oakeshott and Mises on understanding human action", Independent Review, Vol. 10 No. 2, pp. 231-248.

Cardon, M.S., Wincent, J., Singh, J. and Drnovsek, M. (2009), "The nature and experience of entrepreneurial passion", Academy of Management Review, Vol. 34 No. 3, pp. 511-532.

Carlin, M. and Clendenin, N. (2019), "Celestin Freinet's printing press: lessons of a 'bourgeois' educator", Educational Philosophy and Theory, Vol. 51 No. 6, pp. 628-639.

Castree, N. (2010), "Neoliberalism and the biophysical environment 1: what 'neoliberalism'is, and what difference nature makes to it", Geography Compass, Vol. 4 No. 12, pp. 1725-1733.

Celio, C.I., Durlak, J. and Dymnicki, A. (2011), "A meta-analysis of the impact of service-learning on students", Journal of Experiential Education, Vol. 34 No. 2, pp. 164-181.

Chabot, D. and Chabot, M. (2004), Emotional Pedagogy,Trafford Publishing Victoria, BC. 
Chatzichristou, S., Curth, A., Feifa, I., Gosset, M., Kadunc, M., Mosca, M., Vale, P., Williamson, N., Allinson, R. and Håkansson, A. (2015), Entrepreneurship Education: A Road to Success - 13 Case Studies, European Commission, Brussels.

Cook, T.D. (2002), "Randomized experiments in educational policy research: a critical examination of the reasons the educational evaluation community has offered for not doing them", Educational Evaluation and Policy Analysis, Vol. 24 No. 3, pp. 175-199.

Cope, J. (2003), "Entrepreneurial learning and critical reflection”, Management Learning, Vol. 34 No. 4, pp. 429-450.

Cope, J. and Watts, G. (2000), "Learning by doing - an exploration of experience, critical incidents and reflection in entrepreneurial learning", International Journal of Entrepreneurial Behaviour \& Research, Vol. 6 No. 3, pp. 104-124.

Corbin, J. and Strauss, A. (1990), Basics of Qualitative Research: Grounded Theory Procedures and Techniques, Sage Publications, Newbury Park, CA.

Dal, M., Elo, J., Leffler, E., Svedberg, G. and Westerberg, M. (2016), "Research on pedagogical entrepreneurship-a literature review based on studies from Finland, Iceland and Sweden", Education Inquiry, Vol. 7 No. 2, pp. 159-182.

Damasio, A.R. (1994), Descartes' Error, G.P. Putnam's Sons, New York.

Dewey, J. (1938), Experience and Education, Kappa Delta Pi, Indianapolis.

Dhliwayo, S. (2008), "Experiential learning in entrepreneurship education: a prospective model for South African tertiary institutions", Education + Training, Vol. 50 No. 4, pp. 329-340.

Dirkx, J.M. (2001), "The power of feelings: emotion, imagination, and the construction of meaning in adult learning", New Directions for Adult and Continuing Education, Vol. 2001 No. 89, pp. 63-72.

Dochy, F., Segers, M., Van den Bossche, P. and Gijbels, D. (2003), "Effects of problem-based learning: a meta-analysis", Learning and Instruction, Vol. 13 No. 5, pp. 533-568.

Draycott, M. and Rae, D. (2011), "Enterprise education in schools and the role of competency frameworks", International Journal of Entrepreneurial Behaviour \& Research, Vol. 17 No. 2, pp. 127-145.

Dubois, A. and Gadde, L.-E. (2002), "Systematic combining: an abductive approach to case research", Journal of Business Research, Vol. 55 No. 7, pp. 553-560.

Dwerryhouse, R. (2001), "Real work in the 16-19 curriculum: AVCE business and Young Enterprise", Education + Training, Vol. 43 No. 3, pp. 153-162.

Egan, K. (2002), Getting it Wrong from the Beginning: Our Progressivist Inheritance from Herbert Spencer, John Dewey, and Jean Piaget, Yale University Press, London.

Elert, N., Andersson, F. and Wennberg, K. (2014), "The impact of entrepreneurship education in high school on long-term entrepreneurial performance", Journal of Economic Behavior \& Organization, Vol. 111 No. 1, pp. 209-223.

Erkkilä, K. (2000), Entrepreneurial Education: Mapping the Debates in the United States, the United Kingdom and Finland, Taylor \& Francis, Abingdon.

European Commission (2005), Mini-Companies in Secondary Education, Best Procedure Project, Brussels.

Fayolle, A. (2007), Entrepreneurship and New Value Creation: The Dynamic of the Entrepreneurial Process, Cambridge University Press, Cambridge.

Fayolle, A. (2013), "Personal views on the future of entrepreneurship education", Entrepreneurship \& Regional Development, Vol. 25 Nos 7-8, pp. 692-701.

Fayolle, A. and Gailly, B. (2008), "From craft to science - teaching models and learning processes in entrepreneurship education", Journal of European Industrial Training, Vol. 32 No. 7, pp. 569-593. 
IJEBR

26,5

966

Fisher, S., Graham, M. and Compeau, M. (2008), "Starting from scratch: understanding the learning outcomes of undergraduate entrepreneurship education", in Harrison, R.T. and Leitch, C. (Eds), Entrepreneurial Learning: Conceptual Frameworks and Applications, Routledge, New York, NY, pp. 313-340.

Fiske, S.T. (2008), "Core social motivations - views from the couch, consciousness, classroom, computers, and collectives", in Shah, J. and Gardner, W. (Eds), Handbook of Motivation Science, Guilford Press, New York, NY, pp. 3-22.

Flanagan, J.C. (1954), "The critical incident technique”, Psychological Bulletin, Vol. 51 No. 4, p. 327.

Fredricks, J.A., Blumenfeld, P.C. and Paris, A.H. (2004), "School engagement: potential of the concept, state of the evidence", Review of Educational Research, Vol. 74 No. 1, pp. 59-109.

Freinet, C. (1993), Education through Work: A Model for Child-Centered Learning, Edwin Mellen Press, Lewiston, NY.

Furco, A. (1996), "Service-learning: a balanced approach to experiential education", in C f N Service (Ed.), Expanding Boundaries: Serving and Learning, Cooperative Education Association, Columbia, MD, pp. 2-6.

Gartner, W.B. (1989), "Who is an entrepreneur? Is the wrong question", Entrepreneurship: Theory and Practice, Vol. 13 No. 4, pp. 47-68.

Gibb, A. (2002), 'In pursuit of a new 'enterprise' and 'entrepreneurship' paradigm for learning: creative destruction, new values, new ways of doing things and new combinations of knowledge", International Journal of Management Reviews, Vol. 4 No. 3, pp. 233-269.

Gibb, A. (2008), "Entrepreneurship and enterprise education in schools and colleges: insights from UK practice", International Journal of Entrepreneurship Education, Vol. 6 No. 2, p. 48.

Gielnik, M.M., Frese, M., Kahara-Kawuki, A., Wasswa Katono, I., Kyejjusa, S., Ngoma, M., Munene, J., Namatovu-Dawa, R., Nansubuga, F. and Orobia, L. (2015), "Action and action-regulation in entrepreneurship: evaluating a student training for promoting entrepreneurship", The Academy of Management Learning and Education, Vol. 14 No. 1, pp. 69-94.

Gill, R. (2014), "If you're struggling to survive day-to-day': class optimism and contradiction in entrepreneurial discourse", Organization, Vol. 21 No. 1, pp. 50-67.

Günzel-Jensen, F., Moberg, K., Mauer, R. and Neergaard, H. (2017), "Self-efficacy and the entrepreneurial mindset revisited", in Brännback, M. and Carsrud, A. (Eds), Revisiting the Entrepreneurial Mind, Springer, Cham, pp. 319-335.

Hägg, G. (2016), "From liberal progressive education to neo-liberal enterprising self's - a policy perspective", paper presented at the ECSB Entrepreneurship Education Conference, Leeds, UK, May 2016, pp. 11-13.

Hägg, G. and Gabrielsson, J. (2019), "A systematic literature review of the evolution of pedagogy in entrepreneurial education research", International Journal of Entrepreneurial Behavior \& Research, (In press).

Hägg, G. and Kurczewska, A. (2016), "Connecting the dots: a discussion on key concepts in contemporary entrepreneurship education”, Education + Training, Vol. 58 Nos 7/8, pp. $700-714$.

Handscombe, R.D., Rodriguez-Falcon, E. and Patterson, E.A. (2008), "Embedding enterprise in science and engineering departments", Education + Training, Vol. 50 No. 7, pp. 615-625.

Haneberg, D.H. and Aadland, T. (2019), "Learning from venture creation in higher education", Industry and Higher Education, 0950422219884020.

Hannon, P.D. (2005), "Philosophies of enterprise and entrepreneurship education and challenges for higher education in the UK", The International Journal of Entrepreneurship and Innovation, Vol. 6 No. 2, pp. 105-114.

Hannon, P.D. (2018), "On becoming and being an entrepreneurship educator: a personal reflection", Entrepreneurship \& Regional Development, Vol. 30 Nos 7-8, pp. 698-721. 
Harris, R. and Deißinger, T. (2003), "Learning cultures for apprenticeships: a comparison of Germany and Australia", paper presented at the 11th International Conference on Post-Compulsory Education and Training.

Hattie, J. (2008), Visible Learning: A Synthesis of over 800 Meta-Analyses Relating to Achievement, Routledge, London.

Hattie, J. (2017), "Updated list of factors influencing student achievement", London, available at: https://visible-learning.org/wp-content/uploads/2018/03/VLPLUS-252-Influences-Hattie-rankingDEC-2017.pdf (accessed 9 November 2019).

Hedström, P. and Wennberg, K. (2017), "Causal mechanisms in organization and innovation studies", Innovation, Vol. 19 No. 1, pp. 91-102.

Hedström, P. and Ylikoski, P. (2010), "Causal mechanisms in the social sciences”, Annual Review of Sociology, Vol. 36, pp. 49-67.

Hektner, J.M., Schmidt, J.A. and Csikszentmihalyi, M. (2007), Experience Sampling Method - Measuring the Quality of Everyday Life, Sage Publications, London.

Hilgard, E.R. (1980), "The trilogy of mind: cognition, affection, and conation", Journal of the History of the Behavioral Sciences, Vol. 16 No. 2, pp. 107-117.

Hindle, K. (2010), "How community context affects entrepreneurial process: a diagnostic framework", Entrepreneurship and Regional Development, Vol. 22 Nos 7-8, pp. 599-647.

Honig, B. (2004), "Entrepreneurship education: toward a model of contingency-based business planning", The Academy of Management Learning and Education, Vol. 3 No. 3, pp. 258-273.

Hoppe, M., Hoppe, M., Westerberg, M., Westerberg, M., Leffler, E. and Leffler, E. (2017), "Educational approaches to entrepreneurship in higher education: a view from the Swedish horizon", Education + Training, Vol. 59 Nos. 7/8, pp. 751-767.

Hutchison, A.J., Johnston, L.H. and Breckon, J.D. (2010), "Using QSR-NVivo to facilitate the development of a grounded theory project: an account of a worked example", International Journal of Social Research Methodology, Vol. 13 No. 4, pp. 283-302.

Hytti, U., Stenholm, P., Heinonen, J. and Seikkula-Leino, J. (2010), "Perceived learning outcomes in entrepreneurship education: the impact of student motivation and team behavior", Education + Training, Vol. 52 Nos 8/9, pp. 587-606.

Jarvis, P. (2006), Towards a Comprehensive Theory of Human Learning, Routledge, New York, NY.

Johannisson, B. (2010), "The agony of the Swedish school when confronted by entrepreneurship", in Skogen, K. and Sjovoll, J. (Eds), Creativity and Innovation. Preconditions for Entrepreneurial Education, Tapir Academic Press, Trondheim, pp. 91-105.

Johansen, V. and Clausen, T.H. (2011), "Promoting the entrepreneurs of tomorrow: entrepreneurship education and start-up intentions among schoolchildren", International Journal of Entrepreneurship and Small Business, Vol. 13 No. 2, pp. 208-219.

Johnson, D.W., Johnson, R.T. and Stanne, M.B. (2000), Cooperative Learning Methods: A MetaAnalysis, University of Minnesota, Minneapolis, MN (accessed 1 April 2004).

Jones, C. (2011), Teaching Entrepreneurship to Undergraduates, Edward Elgar Publishing, Cheltenham.

Jones, B. and Iredale, N. (2010), "Enterprise education as pedagogy", Education + Training, Vol. 52 No. 1, pp. 7-19.

Jones, S. and Underwood, S. (2017), "Understanding students' emotional reactions to entrepreneurship education: a conceptual framework", Education + Training, Vol. 59 Nos 7/8, pp. 657-671.

Jones, C., Penaluna, K. and Penaluna, A. (2019), "The promise of andragogy, heutagogy and academagogy to enterprise and entrepreneurship education pedagogy", Education + Training, Vol. 61 No. 9, pp. 1170-1186.

Kaider, F., Hains-Wesson, R. and Young, K. (2017), "Practical typology of authentic work-integrated learning activities and assessments", Asia-Pacific Journal of Cooperative Education, Vol. 18 No. 2, pp. 153-165. 
IJEBR

26,5

968

Katz, J.A. (2008), "Fully mature but not fully legitimate: a different perspective on the state of entrepreneurship education*", Journal of Small Business Management, Vol. 46 No. 4, pp. 550-566.

Komulainen, K., Naskali, P., Korhonen, M. and Keskitalo-Foley, S. (2011), "Internal entrepreneurshipA Trojan horse of the neoliberal governance of education? Finnish pre-and in-service teachers' implementation of and resistance towards entrepreneurship education", Journal for Critical Education Policy Studies, Vol. 9 No. 1, pp. 341-374.

Korhonen, M., Komulainen, K. and Räty, H. (2012), “'Not everyone is cut out to be the entrepreneur type": how Finnish school teachers construct the meaning of entrepreneurship education and the related abilities of the pupils", Scandinavian Journal of Educational Research, Vol. 56 No. 1, pp. 1-19.

Korsgaard, S. and Anderson, A.R. (2011), "Enacting entrepreneurship as social value creation", International Small Business Journal, Vol. 29 No. 2, pp. 135-151.

Kozlinska, I. (2016), Evaluation of the Outcomes of Entrepreneurship Education Revisited, Doctoral Thesis, University of Turku, Turku.

Kubberød, E. and Pettersen, I.B. (2017), "Exploring situated ambiguity in students' entrepreneurial learning", Education + Training, Vol. 59 No. 3, pp. 265-279.

Kyrö, P. (2005), "Entrepreneurial learning in a cross-cultural context challenges previous learning paradigms", in Kyrö, P. and Carrier, C. (Eds), The Dynamics of Learning Entrepreneurship in a Cross-Cultural University Context, Vol. Entrepreneurship Education Series 2/2005, University of Tampere, Hämeenlinna.

Labaree, D.F. (2005), "Progressivism, schools and schools of education: an American romance", Paedagogica Historica, Vol. 41 Nos 1-2, pp. 275-288.

Lackéus, M. (2014), “An emotion based approach to assessing entrepreneurial education”, International Journal of Management in Education, Vol. 12 No. 3, pp. 374-396.

Lackéus, M. (2016), Value Creation as Educational Practice - towards a New Educational Philosophy Grounded in Entrepreneurship? Doctoral Thesis, Chalmers University of Technology, Gothenburg.

Lackéus, M. (2017), “Does entrepreneurial education trigger more or less neoliberalism in education?”, Education + Training, Vol. 59 No. 6, pp. 635-650.

Lackéus, M. and Sävetun, C. (2019), "Assessing the impact of enterprise education in three leading Swedish compulsory schools", Journal of Small Business Management, Vol. 57 No. S1, pp. 33-59.

Lackéus, M., Lundqvist, M. and Williams Middleton, K. (2016), "Bridging the traditional - progressive education rift through entrepreneurship", International Journal of Entrepreneurial Behavior \& Research, Vol. 22 No. 6, pp. 777-803.

Lans, T., Tynjälä, P., Biemans, H., Ratinho, T. and Karimi, S. (2017), "Entrepreneurship education with impact: opening the black box", Education Research International, 2017.

Lave, J. and Wenger, E. (1991), Situated Learning: Legitimate Peripheral Participation, Cambridge University Press, Cambridge.

Leffler, E. (2009), "The Many Faces of Entrepreneurship: a discursive battle for the school arena", European Educational Research Journal, Vol. 8 No. 1, pp. 104-116.

Little, D. (1991), Varieties of Social Explanation, Westview Press, Boulder, CO.

Löbler, H. (2006), "Learning entrepreneurship from a constructivist perspective", Technology Analysis \& Strategic Management, Vol. 18 No. 1, pp. 19-38.

Longva, K.K. and Foss, L. (2018), "Measuring impact through experimental design in entrepreneurship education: a literature review and research agenda", Industry and Higher Education, Vol. 32 No. 6, pp. 358-374.

Maritz, A. and Brown, C.R. (2013), "Illuminating the black box of entrepreneurship education programs", Education + Training, Vol. 55 No. 3, pp. 234-252. 
Martin, B.C., McNally, J.J. and Kay, M.J. (2013), "Examining the formation of human capital in entrepreneurship: a meta-analysis of entrepreneurship education outcomes", Journal of Business Venturing, Vol. 28 No. 2, pp. 211-224.

McCrea, E.A. (2009), "Integrating service-learning into an introduction to entrepreneurship course", Journal of Management Education, Vol. 34 No. 1, pp. 39-61.

McKnight, L. and Whitburn, B. (2018), "Seven reasons to question the hegemony of visible learning", Discourse: Studies in the Cultural Politics of Education, Vol. 41 No. 1, pp. 32-44.

Merton, R.K. (1968), Social Theory and Social Structure, Simon and Schuster, New York, NY.

Miller, T.L., Grimes, M.G., McMullen, J.S. and Vogus, T.J. (2012), "Venturing for others with heart and head: how compassion encourages social entrepreneurship", Academy of Management Review, Vol. 37 No. 4, pp. 616-640.

Moberg, K. (2014a), "Assessing the impact of entrepreneurship education - from $\mathrm{ABC}$ to $\mathrm{PhD}$ ", Doctoral Thesis, Copenhagen Business School.

Moberg, K. (2014b), "Two approaches to entrepreneurship education: the different effects of education for and through entrepreneurship at the lower secondary level", International Journal of Management in Education, Vol. 12 No. 3, pp. 512-528.

Montessori, M. (1912), The Montessori Method: Frederick A, Stokes Company, New York.

Nabi, G., Liñán, F., Fayolle, A., Krueger, N. and Walmsley, A. (2017), "The impact of entrepreneurship education in higher education: a systematic review and research agenda", The Academy of Management Learning and Education, Vol. 16 No. 2, pp. 277-299.

Neck, H.M. and Corbett, A.C. (2018), "The scholarship of teaching and learning entrepreneurship", Entrepreneurship Education and Pedagogy, Vol. 1 No. 1, pp. 8-41.

Neck, H.M. and Greene, P.G. (2011), "Entrepreneurship education: known worlds and new frontiers", Journal of Small Business Management, Vol. 49 No. 1, pp. 55-70.

Neck, H.M., Greene, P.G. and Brush, C.G. (2014), Teaching Entrepreneurship: A Practice-Based Approach, Edward Elgar Publishing, Cheltenham.

Oakeshott, M. (1991), On Human Conduct, Oxford University Press, Oxford.

Ollila, S. and Williams-Middleton, K. (2011), "The venture creation approach: integrating entrepreneurial education and incubation at the university", International Journal of Entrepreneurship and Innovation Management, Vol. 13 No. 2, pp. 161-178.

Pepin, M. (2012), "Enterprise education: a Deweyan perspective”, Education + Training, Vol. 54 Nos 8/ 9, pp. 801-812.

Pepin, M. and St-Jean, E. (2018), "Assessing the impacts of school entrepreneurial initiatives: a quasiexperiment at the elementary school level”, Journal of Small Business and Enterprise Development, Vol. 26 No. 2, pp. 273-288.

Peterman, N.E. and Kennedy, J. (2003), "Enterprise education: influencing students' perceptions of entrepreneurship", Entrepreneurship: Theory and Practice, Vol. 28 No. 2, pp. 129-144.

Pittaway, L. and Cope, J. (2007), "Simulating entrepreneurial learning”, Management Learning, Vol. 38 No. 2, pp. 211-233.

Postle, D. (1993), "Putting the heart back into learning", in Boud, D., Cohen, R. and Walker, D. (Eds), Using experience for Learning London: Society for Research into Higher Education and Open University Press, pp. 33-45.

Pring, R. (2010), Philosophy of Educational Research, Continuum International Publishing, London.

Puente, S.M.G., van Eijck, M. and Jochems, W. (2013), "A sampled literature review of design-based learning approaches: a search for key characteristics", International Journal of Technology and Design Education, Vol. 23 No. 3, pp. 717-732.

QAA (2012), Enterprise and Entrepreneurship Education: Guidance for UK Higher Education Providers, The Quality Assurance Agency for Higher Education, Gloucester. 
IJEBR

26,5

970

QAA. (2018), Enterprise and Entrepreneurship Education: Guidance for UK Higher Education Providers, The Quality Assurance Agency for Higher Education, Gloucester.

Rae, D. (2010), "Universities and enterprise education: responding to the challenges of the new era", Journal of Small Business and Enterprise Development, Vol. 17 No. 4, pp. 591-606.

Rae, D. (2013), "The contribution of momentary perspectives to entrepreneurial learning and creativity", Industry and Higher Education, Vol. 27 No. 6, pp. 407-420.

Ramsgaard, M.B. (2018), "Experiential learning philosophies of enterprise and entrepreneurship education", in Experiential Learning for Entrepreneurship, Springer, London, pp. 3-18.

Rasmussen, A. and Nybye, N. (2013), "Entrepreneurship education: progression model", The Danish Foundation for Entrepreneurship - Young Enterprise, Odense.

Rasmussen, E.A. and Sørheim, R. (2006), “Action-based entrepreneurship education”, Technovation, Vol. 26 No. 2, pp. 185-194.

Renko, M. (2013), "Early challenges of nascent social entrepreneurs", Entrepreneurship: Theory and Practice, Vol. 37 No. 5, pp. 1045-1069.

Richard, D. (2012), The Richard Review of Apprenticeships, School for Startups, London.

Rideout, E.C. and Gray, D.O. (2013), "Does entrepreneurship education really work? A review and methodological critique of the empirical literature on the effects of university-based entrepreneurship education”, Journal of Small Business Management, Vol. 51 No. 3, pp. 329-351.

Roberts, J.W. (2012), Beyond Learning by Doing: Theoretical Currents in Experiential Education, Routledge, New York, NY.

Rousseau, J.-J. (1762), Émile or Treatise on Education, Vol. 3, Prometheus Books, Amherst, New York.

Sagar, H. (2015), Entrepreneurial Schools - Part 2 - Entrepreneurial Learning Environments and a Changed Role for Teachers, OECD, Paris.

Sarasvathy, S.D. and Venkataraman, S. (2011), "Entrepreneurship as method: open questions for an entrepreneurial future", Entrepreneurship: Theory and Practice, Vol. 35 No. 1, pp. 113-135.

Savery, J.R. and Duffy, T.M. (1995), "Problem based learning: an instructional model and its constructivist framework", Educational Technology, Vol. 35 No. 5, pp. 31-38.

Sayer, A. (2010), Method in Social Science: A Realist Approach, Routledge, New York, NY.

Shane, S.A. (2003), A General Theory of Entrepreneurship: The Individual-Opportunity Nexus, Edward Elgar Publishing, Cheltenham.

Shane, S. and Venkataraman, S. (2000), "The promise of entrepreneurship as a field of research", Academy of Management Review, Vol. 25 No. 1, pp. 217-226.

Slavin, R.E. (2002), "Evidence-based education policies: transforming educational practice and research”, Educational Researcher, Vol. 31 No. 7, pp. 15-21.

Smith, A.J., Collins, L.A. and Hannon, P.D. (2006), "Embedding new entrepreneurship programmes in UK higher education institutions: challenges and considerations", Education + Training, Vol. 48 Nos 8/9, pp. 555-567.

Smith, C., Ferns, S. and Russell, L. (2014), "The impact of work integrated learning on student workreadiness", Department of Education: Australian Government.

Snell, R. (1992), “Experiential learning at work: why can’t it be painless?”, Personnel Review, Vol. 21 No. 4, pp. 12-26.

Souitaris, V., Zerbinati, S. and Al-Laham, A. (2007), "Do entrepreneurship programmes raise entrepreneurial intention of science and engineering students? The effect of learning, inspiration and resources", Journal of Business Venturing, Vol. 22 No. 4, pp. 566-591.

Stone, A.A., Shiffman, S.S. and DeVries, M.W. (2003), "2 - ecological momentary assessment", in Kahneman, D., Diener, E. and Schwarz, N. (Eds), Well-being: The Foundations of Hedonic Psychology, Russell Sage Foundation, New York. 
Tan, S.S. and Ng, C.K.F. (2006), "A problem-based learning approach to entrepreneurship education", Education + Training, Vol. 48 No. 6, pp. 416-428.

Thorngate, W. (1976), ““ in general” vs. “it depends”: some comments of the gergen-schlenker debate”, Personality and Social Psychology Bulletin, Vol. 2 No. 4, pp. 404-410.

Tobias, S. and Duffy, T.M. (2009), Constructivist Instruction - Success or Failure?, Routledge, New York.

Vestergaard, L., Moberg, K. and Jørgensen, C. (2012), Impact of Entrepreneurship Education in Denmark - 2011, Denmark: The Danish Foundation for Entrepreneurship - Young Enterprise, Odense.

von Mises, L. (1949), Human Action: A Treatise on Economics, The Ludwig von Mises Institute, Auburn, Alabama.

Weick, K.E. (1979), The Social Psychology of Organizing, Addison-Wesley Publishing, Reading, MA.

Ylikoski, P. (2019), "Mechanism-based theorizing and generalization from case studies", Studies in History and Philosophy of Science, Vol. 78, pp. 14-22.

Young, D.I. (2014), Enterprise for All: The Relevance of Enterprise in Education, Department for Business, Innovation \& Skills, Office of the Prime Minister, London.

\section{Supplementary material}

Five of the six data collection waves have been summarised in internal reports in Swedish, or separate articles in English.

\section{Wave 1}

Lackéus, M. (2014), “An emotion based approach to assessing entrepreneurial education”, International Journal of Management Education, Vol. 12 No. 3, pp. 374-396.

\section{Wave 2}

Lackéus, M. and Sävetun, C. (2014), Att mäta det omätbara, Framtidsfrön i Väst, , Gothenburg.

\section{Wave 3}

Lackéus, M. and Sävetun, C. (2015), Elevperspektiv från tre entreprenöriella lärmiljöer i svensk grundskola - en effektstudie genomförd på uppdrag av Skolverket, Chalmers Publication Library, Göteborg.

Lackéus, M. and Sävetun, C. (2019), “Assessing the Impact of Enterprise Education in Three Leading Swedish Compulsory Schools", Journal of Small Business Management, Vol. 57 No. S1, pp. 33-59.

\section{Wave 4}

Lackéus, M. and Sävetun, C. (2016b), Koncept kontra skola: En studie av åtta entreprenöriella lärmiljöer En effektstudie på uppdrag av Region Skåne, Chalmers Publications, Gothenburg.

\section{Wave 6}

Lackéus, M. and Sävetun, C. (2016a), Entreprenöriell utbildning som värdeskapande lärande - en tredje väg? En effektstudie av värdeskapande lärande på uppdrag av Skolverket, Chalmers University of Technology, Gothenburg.

\section{Corresponding author}

Martin Lackéus can be contacted at: martin.lackeus@chalmers.se

For instructions on how to order reprints of this article, please visit our website:

www.emeraldgrouppublishing.com/licensing/reprints.htm

Or contact us for further details: permissions@emeraldinsight.com 